\title{
Complex Characteristic of Zircon from Granitoids of the Verkhneurmiysky Massif (Amur Region)
}

\author{
Maria M. Machevariani ${ }^{1}$, Alexey V. Alekseenko ${ }^{2, *(D)}$ and Jaume Bech ${ }^{3}$ \\ 1 Department of Mineralogy, Crystallography, and Petrography, Saint Petersburg Mining University, \\ 199106 Saint Petersburg, Russia; wmdmaria@gmail.com \\ 2 Department of Geoecology, Saint Petersburg Mining University, 199106 Saint Petersburg, Russia \\ 3 Faculty of Biology, University of Barcelona, 08002 Barcelona, Spain; jaumebechborras@gmail.com \\ * Correspondence: al.vl.alekseenko@gmail.com
}

check for

updates

Citation: Machevariani, M.M. Alekseenko, A.V.; Bech, J. Complex Characteristic of Zircon from Granitoids of the Verkhneurmiysky Massif (Amur Region). Minerals 2021, 11, 86. https://doi.org/10.3390/ $\min 11010086$

Received: 3 November 2020

Accepted: 12 January 2021

Published: 16 January 2021

Publisher's Note: MDPI stays neutral with regard to jurisdictional claims in published maps and institutional affiliations.

Copyright: (c) 2021 by the authors. Licensee MDPI, Basel, Switzerland. This article is an open access article distributed under the terms and conditions of the Creative Commons Attribution (CC BY) license (https:// creativecommons.org/licenses/by/ $4.0 /)$.

\begin{abstract}
The study presents a complex characteristic of zircon from the Verkhneurmiysky intrusive series with Li-F granites. A wide range of morphological and chemical properties of zircon allowed us to obtain new information on the formation and alteration of zircon from biotite and zinnwaldite granitoids and to determine its features, which contribute to the correct definition of Li-F granites formed directly before the tin mineralization. The reviled trends of zircon morphology and composition evolution in the Verkhneurmiysky granites series are: the high-temperature morphotypes are followed by low-temperature ones with more complicated internal structure with secondary alteration zones, mineral inclusions, pores, and cracks; the increasing concentration of volatile $\left(\mathrm{H}_{2} \mathrm{O}, \mathrm{F}\right)$, large ion lithophile (Cs, $\mathrm{Sr})$, high field strength $(\mathrm{Hf}, \mathrm{Nb}$ ) and rare-earth elements with decreasing crystallization temperatures and the determining role of the fluid phase (predominantly, F) in the trace element accumulation. The composition of zircon cores in biotite and zinnwaldite granites is very similar. However, the zircon rims from zinnwaldite granites are much more enriched in trace elements compared to those from biotite granites. The first study of zircon from the Verkhneurmiysky granitoids provides new data on the formation and alteration conditions of granitoids, including zinnwaldite ones.
\end{abstract}

Keywords: zircon crystal morphology; zircon textures; zircon trace elements; alteration of zircon; REE in zircon; rare metal granites; Li-F granites

\section{Introduction}

Granitoid plutons are widespread in the Badzhal and Myao-Chan ridges of the Amur Region and play an important role in the localization of the Badzhal-Komsomolsky tin ore district. At the same time, rare metal Li-F granites formed shortly before tin mineralization were found only in 1987-1990, when an expedition of the Leningrad Mining Institute conducted a special mapping of the territory of the Verkhneurmiysky ore cluster.

In recent years, rare-metal granites were determined only by their chemical composition, without taking into account their geological, mineralogical, and petrographic features. Due to the statistically insignificant differences in the composition of biotite and zinnwaldite granites, this approach leads to errors in geological mapping and mineral prospecting and exploration.

The comprehensive cutting edge study of accessory mineralization, including zircon, which is the most important mineral indicator of petrogenesis, effective geochronometer, and geothermometer, should contribute to the solution to problems of correct granitoid differentiation in the Amur region, the identification of rare-metal granites, and the study of their formation conditions.

The purpose of this study was to identify typomorphic features of accessory zircon from the granites of the Verkhneurmiysky massif. This set of characteristics should improve the scientific and methodological basis for the identification of rare-metal Li-F 
granite within the granitoid plutons. To solve these problems, we studied the composition, morphology, and internal structure of accessory zircon from biotite leucogranites and zinwalditic Li-F granites of the Verkhneurmiysky massif.

\section{Geological Settings of the Verkhneurmiysky Massif and Characteristics of Granitoids}

\subsection{Geological Structure of the Verkhneurmiysky Massif}

The Badzhal tin ore district is a part of the Sikhote-Alin-North-Sakhalin Lower Cretaceous orogenic belt, which extended for about $1500 \mathrm{~km}$ with a northeastern strike and a width of $600 \mathrm{~km}$ from the southern borders of Primorye to the Lower Priamurye and the northern tip of Sakhalin Island. The belt formation began in the Early Cretaceous, Neocomian stage and continued until the late Albian Stage within a transform margin.

From 1950 to 1970, the territory of Badzhal Ridge was studied in detail by the state geological survey for prospecting works. Geological maps at scales of 1:200,000 and 1:50,000 [1] were drawn. Gravimetric survey at scales of 1:100,000 resulted in the establishment of the largest gravimetric minimum in the Amur Region due to the presence of a hidden granite batholith, which includes the Verkhneurmiysky massif.

Late Cretaceous intrusions of biotite granites and leucogranites of the Badzhal complex, accompanied, especially in the east, by small massifs of monzonites, diorites, granodiorites, and granites of the Silinsky complex, significantly prevail in the study area. The general trend in the magmatic evolution is the increasing role of rhyolites and comagmatic granites, increasing alkalinity and potassium content in granitoids [2].

In the 1970s and 1980s, geological exploration was carried out within the Badzhal ore district, which resulted in the discovery of the major Pravourmiyskoye tungsten-copper deposit (balance reserves of 141.5 thousand tonnes of tin, 12.3 thousand tonnes of $\mathrm{WO}_{3}$, and 40.1 tonnes of copper) and some smaller tin-bearing bodies [2]. Ore occurrences with Sn, $\mathrm{W}, \mathrm{Mo}$, and polymetallic deposits are grouped in three local ore clusters: Verkhneurmiysky, Verkhnebadzhalsky, and Hogdu-Lyanchlinsky, connected with extrusive dome structures, which siliceous intrusive and subvolcanic rocks of Badzhal complex in its core zone.

The Verkhneurmiysky tin ore deposit is the largest and most promising object in the southwestern part of the Badzhalsky region. It is notable for its complex geological structure and significant scale of metasomatic alterations. The geological and structural position of the ore node is determined by its confinement to a large Verkhneurmiysky granite massif and sublatitudinal structures $[3,4]$.

The two main ore types are: cassiterite-quartz and cassiterite-silicate assemblages. The age of the Verkhneurmiysky massif is estimated from $83.4 \pm 3.2 \mathrm{Ma}$ to $98 \pm 4$ [2].

The rare metal granites immediately preceding tin mineralization were first found in 1987-1990 [2]. In 1993, a report was published giving a brief characterization of these granites in the Verkhneurmiysky massif, which are classified by petrochemical, geochemical, and mineralogical features as subalkaline rare-metal Li-F leucogranites [5].

Some researchers [6], point to the evolution in the formation of granites of the Verkhneurmiysky massif, which led to the intrusion of more and more evolved granite magmas with the final formation of Li-F granites, which are spatially and genetically associated with the Pravourmiyskoye tin deposit.

They also consider slab window as the most probable mechanism for magmatic rock formation of the Badzhal zone [7], and Li-F granites fluid sources that caused metasomatic alteration of rhyolite with the formation of ore-bearing quartz-topaz-siderophyllite greisens [6].

While the fact of spatial and genetic connection of the Pravourmiyskoye tin ore deposit with the formation of the Li-F granite at the final stage is not in doubt, the question of their genesis remains controversial.

Post-orogenic granitoids of the Verkhneurmiysky pluton are divided into the following types: (1) widespread biotite granites and leucogranites, which form major bodies and are united within the Badzhal complex; (2) rare subalkaline biotite monzodiorites and monzogranites of the Silinsky complex, composing poorly eroded dyke belts and stocks [2,8,9]; (3) rare stocks and dykes of subalkaline rare-metal Li-F granites of the Pravourmiysky complex [10]. 
The Pravourmiysky complex is located in the course of the Irungda-Makit River at the intersection of northwestern Orokotskaya and latitudinal Pravourmiyskaya disjunctive zones (Figure 1, red circle). The exposure of rare-metal granites composes less than $1 \%$ of the Badzhal zone.

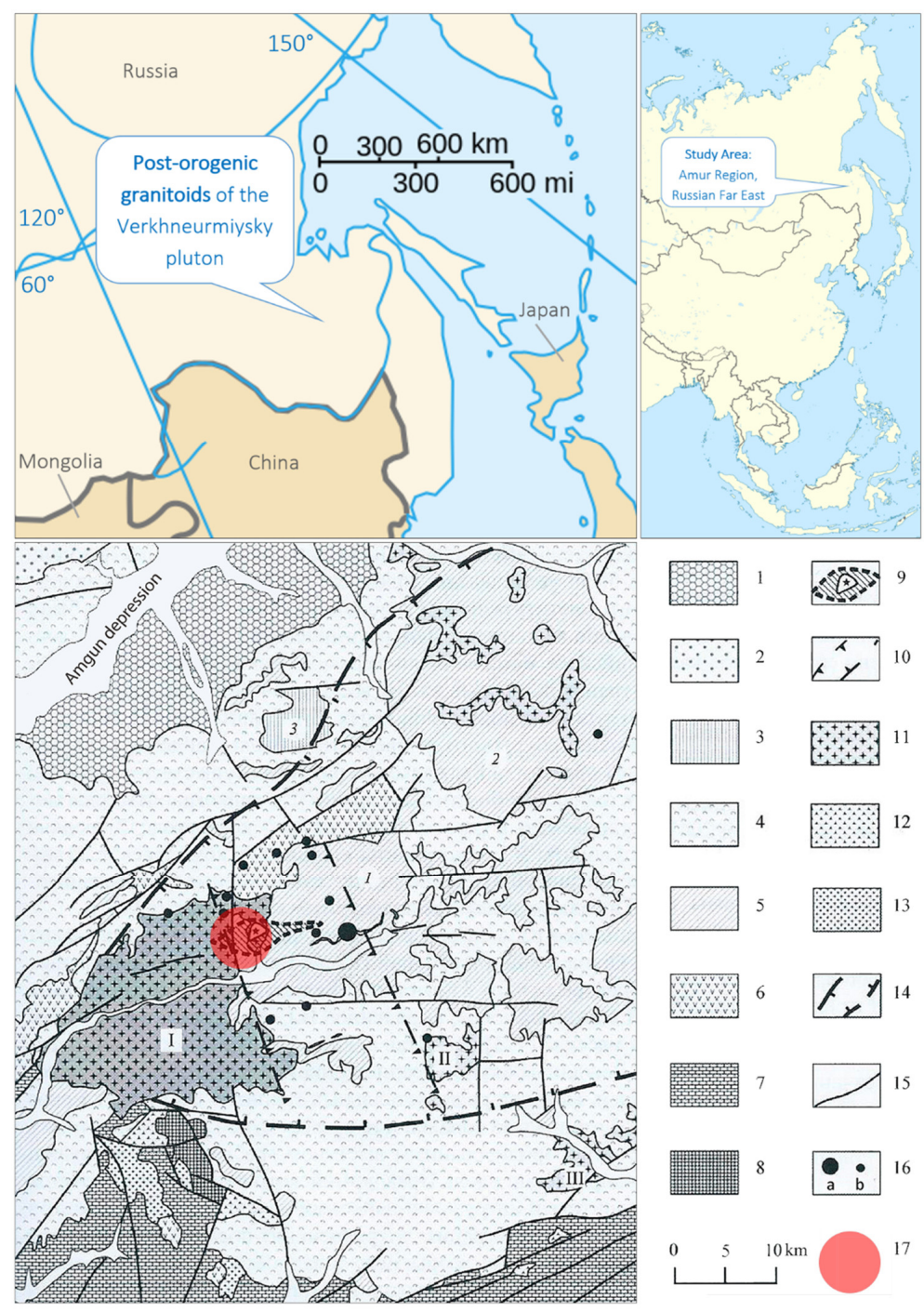

Figure 1. Upper part: Study area, based on the free blank map, commons.wikimedia.org. Lower part: Geological position of Li-F granites in Badzhal region (the scheme is based on the State Geological Map-1000/3, GGK-2009) [2]. 1-Oligocene-Miocene conglomerates, sandstones, argillites of the Verkhneamgunskaya Depression; 2-5-Upper Cretaceous volcanites: 2-Ignimbrites of trachyrhyolites, trachyrhyodacites, 3-Subvolcanic trachyandesites, quartz-monzonite porphyries, 4-Ignimbrites and rhyolites tuff, rhyodacites, 5-Subvolcanic rhyolites, rhyodacites; 6-Lower Cretaceous andesites, andesidacites and their tuffs; 7-Devonian-Perm terrigenous and clayey rocks; 8-Lower Proterozoic gneisses, amphibolites, quartzites; 9-11-Upper Cretaceous intrusive formations: 9-Areal of rare-metal granite magmatism (Pravourmiysky complex), 10—Orokotskaya zone of monzonitoid dyke magmatism (Silinsky complex), 11-Biotite, biotite-hornblende granites, leucogranites (Badzhal complex); 12-Lower and Upper Cretaceous granodiorites, quartz diorites (Laksky complex); 13-Late Paleozoic granites and granodiorites; 14-Boundaries of local minimum gravity of the second order; 15-Faults; 16-Large deposits (a); and ore manifestations (b); 17-Sampling area. Plutons: I-Verkhneurmiysky, II—Synchuginsky, III—Yarapsky. Extrusions: 1-Urmiysky, 2-Gerbinsky, 3-Kurkaltinsky. 


\subsection{Mineral and Chemical Composition of Granitoids of the Verkhneurmiysky Massif}

Here we give a brief geological, petrographic, and geochemical characteristics of biotite granites of the Badzhal complex and zinwalditic granites of the Pravourmiysky complex.

Leucogranites of the Badzhal complex form middle-sized hypabyssal intrusive bodies, which stretch along with the magma-controlling faults. Crystallization of granites of the Badzhal complex lasted several billion years (crystallization started $94-95$ billion years ago and completed $\sim 92-93$ billion years ago) and ended with the intrusion of porphyraceous granite dikes within the Verkhneurmiysky ore cluster.

Leucogranites are characterized by high concentrations of $\mathrm{SiO}_{2}(70-75 \%)$, increased alkalinity $\left(\Sigma\left(\mathrm{K}_{2} \mathrm{O}+\mathrm{Na}_{2} \mathrm{O}\right)\right)=8-9 \%, \mathrm{~K}>\mathrm{Na}$, and alumina, but do not contain minerals with high alumina content. These granites belong to the type of leucogranite-alaskaite formation of tin provinces and are characterized by elevated concentrations of $\mathrm{Li}, \mathrm{Rb}, \mathrm{Cs}, \mathrm{Y}$, $\mathrm{Yb}, \mathrm{W}, \mathrm{Mo}, \mathrm{Sn}$, and lower concentrations of $\mathrm{Ba}$ and Sr. At the same time, the concentrations of $\mathrm{Rb}, \mathrm{Cs}, \mathrm{W}, \mathrm{Nb}, \mathrm{Y}, \mathrm{Yb}$, and $\mathrm{Sc}$ in the granites of later phases increase successively, while the $\mathrm{Ba}$ and $\mathrm{Sr}$ concentrations decrease. Consequently, the fractionation degree of granitoid systems $(\mathrm{Rb} / \mathrm{K}, \mathrm{Rb} / \mathrm{Ba}, \mathrm{Rb} / \mathrm{Sr}, \mathrm{Cs} / \mathrm{K}$, and $\mathrm{K} / \mathrm{Ba})$ increases too. We also revealed an increase in the $\mathrm{Li}, \mathrm{Sn}$, and $\mathrm{F}$ content and a decrease in the Mo concentration [2].

Post-magmatic alterations are widespread in the Badzhal leucogranites, including those acquired under the influence of late zinwalditic rare-metal granites. These alterations make leucogranites and zinwalditic granites quite similar in mineralogical and geochemical composition [2,11].

Li-F granites of the Verkhneurmiysky massif are the youngest intrusive complexes completing the Late Cretaceous rare-metal granite intrusive series [2,12]. According to the tectonic, geological, and structural conditions, as well as petrographic, mineralogical, and geochemical features-these granites belong to the Li-F type of subalkaline leucogranite formation of rare-metal granites. Li-F granites of Verkhneurmiysky massif are zinwalditic tantalum-tungsten-niobium-bearing granites with $\mathrm{Nb}$-wolframite, $\mathrm{W}$-ixiolite, and samarskite, specific for the in post-magmatic tungsten-tin deposits $[13,14]$.

Li-F granites of the Verkhneurmiysk massif are characterized by a massive or eutaxitic texture, light gray or white color, and the same crystallinity as the host medium-grained leucogranite. Macroscopically, leucogranites are characterized by a lighter color, absence of porphyraceous phenocrysts, and chain aggregation of quartz. Rock-forming minerals are K-feldspar (33-43 vol.\%), albite (27-38 vol.\%), quartz (32-36 vol.\%), and zinnwaldite (3-5 vol.\%). Characteristic features of the Verkhneurmiysky Li-F granites are zinnwaldite nodules (up to $0.6 \mathrm{~mm}$ ) with inclusions of fluorite and plagioclase with incorporated topaz crystals. The rounded pea-shaped quartz forms chains and snowball structures. Mica of the zinnwaldite series was defined as a Li-bearing siderophyllite that differs from the biotite of leucogranites by the increased content of $\mathrm{Al}, \mathrm{Li}, \mathrm{Mn}$, and lower concentrations of $\mathrm{Mg}, \mathrm{Fe}$, and Ti [2].

The composition of the main accessory minerals of zinnwaldite granites differs significantly from biotite ones. The zinnwaldite granites contain topaz, fluorite, fluocerite, ixiolite-(W), fergusonite-(Y), ferberite, while apatite, allanite-(Ce), and anatase are absent. In addition, zinnwaldite granites have higher contents of zircon, monazite-(Ce), xenotime$(\mathrm{Y})$, thorite and decreased fraction of ilmenite and rutile [15]. One of the main typomorphic features of zinnwaldite granites is the presence of rare-earth and rare-metal-bearing minerals. They are characterized by the stable presence of $\mathrm{W}$ (fergusonite- $(\mathrm{Y})$, calciosamarskite, samarskite- $(\mathrm{Yb})$, eschinite- $(\mathrm{Y})$, strüverite, ilmenite, liandratite), the predominance of $\mathrm{Nb}$ over Ta, a significant role of $\mathrm{As}, \mathrm{Bi}, \mathrm{Th}$, and $\mathrm{U}$, and low content of Sn. Thus, the feature of Li-F granites is the presence of $\mathrm{W}$ and Y-rare-earth elements (REE)-Nb-bearing mineralization [10].

Thus, we can conclude that the detection of ore-bearing granites within the Verkhneurmiysky massif is a promising task for modern geological exploration. The exploration for rare-metal mineralization in this region should consider not only the spatial and genetic relationship of Li-F granites with plutons of leucogranites and small intrusions of mon- 
zonites, but also all identified mineralogical and petrographic features of Li-F granites, including the detailed characteristics of the accessory minerals and, first of all-zircon. The comprehensive study of granitoids of the Verkhneurmiysky massif, described in the works of V.A. Alekseev, Yu.B. Marin, et al. [2,12], allow identifying the initial and final members of the Verkhneurmiyskaya granitoid series: biotite leucogranites of the Badzhal complex and zinnwaldite granites of the Pravourmiysky complex [2].

To clarify the geochemical types of biotite and zinnwaldite granite samples under study (Figure 2) and to compare them with the other granites of a similar genesis-we performed a bulk chemical analysis (XRF for petrogenic elements, ICP-MS for an extended set of elements).

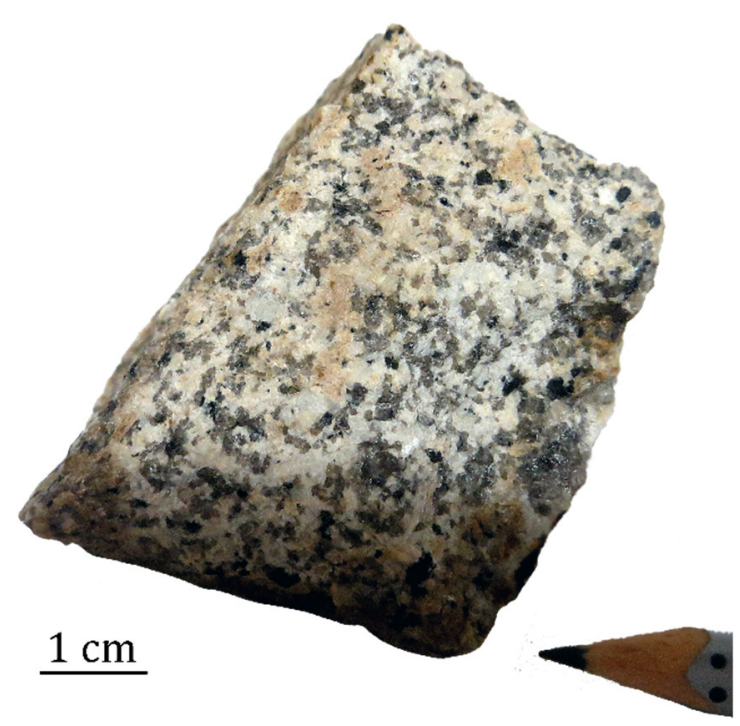

(a)

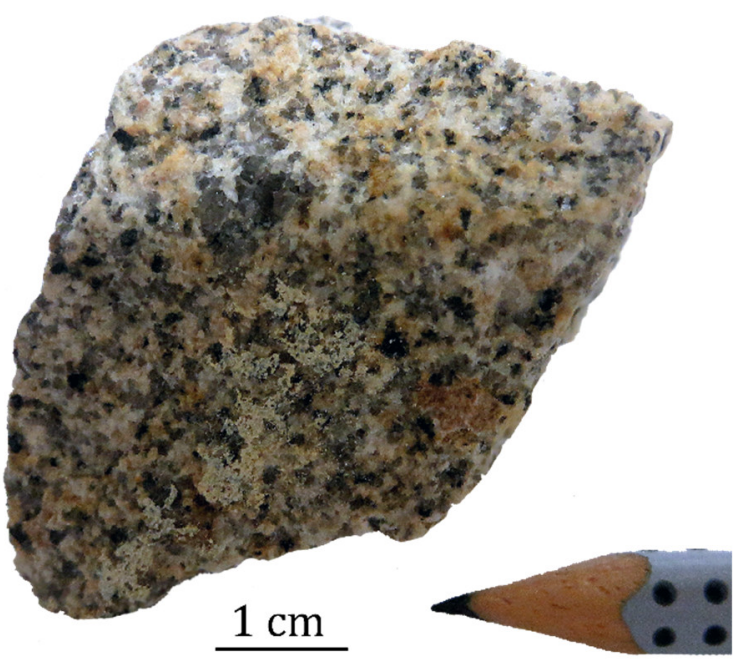

(b)

Figure 2. Chip samples of Li-F granites from Verkhneurmiysky massif: (a) medium-grained zinnwaldite granite; (b) mediumgrained biotite granite.

The table of contents of granites from the Verkhneurmiysky massif, Severny massif (Chukotka), as well as zinnwaldite and protolithionitic granites from Erzgebirge (Germany) (Table 1) and their position on the Frost diagram [16] (Figure 3a) demonstrate that studied Verkhneurmiysky's granites are subalkaline and all of the compared rocks are rather similar in terms of the ratio of major oxides. Moreover, not only biotite and zinnwaldite granites compositions are close, but also the compositions of granites of the Far East, Chukotka, and the Erzgebirge in general.

The content of trace elements (Figure 3b) in biotite leucogranites reflects a rare metal melt nature, however, less contrasting than in the zinnwaldite Li-F granites of both Far Eastern massifs. Elevated concentrations of Li, F, Rb, Cs, Sn, W, Nb, Ta, Y, REE, Th, and other granitophile elements were also observed [2,10], with the accumulation of volatile $(\mathrm{F})$, rare alkaline $(\mathrm{Li}, \mathrm{Rb})$ and some high field strength elements $(\mathrm{Nb}, \mathrm{Ta})$ in the zinnwaldite granites of the Erzgebirge. Some elements $(\mathrm{Ba}, \mathrm{Sr}, \mathrm{Zr}$ ) in biotite granites have concentrations below the relative abundance of the elements and predictably increase in Li-F granites.

Comparison of the elemental composition of the studied granitoids is consistent with the geochemical evolution of the Far Eastern granitoid complexes [2], expressed in an increase in alumina content, accumulation of rare elements, reducing the values of $\mathrm{K} / \mathrm{Rb}$ (Bt-Gr-0.67, Znw-Gr-0.64), Nb/Ta (Bt-Gr-7.7, Znw-Gr-5.1), a sharp increase in Rb/Sr (Bt-Gr-15.3, Znw-Gr-22.4), and a deepening of Eu anomaly on the course from biotite to zinnwaldite granites. 
Table 1. The composition (single measurements) of granites of the Verkhneurmiysky massif (Amur region), Severny massif (Chukotka), and Erzgebirge (Germany, Czech Republic) according to published data $[2,17]$ and the samples analyzed in this paper $\left(^{*}\right)$; Bt-Biotite granite, Znw-Zinnwaldite granite, Pr-Protolithionitic granite.

\begin{tabular}{|c|c|c|c|c|c|c|c|c|}
\hline & \multicolumn{4}{|c|}{ Verkhneurmiysky Massif } & \multicolumn{2}{|c|}{ Severny Massif } & \multicolumn{2}{|c|}{ Erzgebirge } \\
\hline & $\mathbf{B t}$ * & Znw * & Bt & Znw & Bt & Znw & $\operatorname{Pr}$ & Znw \\
\hline $\mathrm{SiO}_{2}$ & 75.71 & 76.95 & 76.38 & 76.63 & 75.46 & 77.59 & 75.53 & 72.22 \\
\hline $\mathrm{TiO}_{2}$ & 0.07 & 0.07 & 0.13 & 0.03 & 0.13 & 0.06 & 0.07 & 0.01 \\
\hline $\mathrm{Al}_{2} \mathrm{O}_{3}$ & 13.03 & 12.18 & 12.48 & 13.08 & 11.72 & 10.9 & 12.54 & 15.92 \\
\hline $\mathrm{Fe}_{2} \mathrm{O}_{3}$ & 1.59 & 1.93 & 0.27 & 0.15 & 1.68 & 1.49 & 0.6 & 0.2 \\
\hline $\mathrm{FeO}$ & - & - & 1.58 & 1.09 & - & - & 0.78 & 0.45 \\
\hline $\mathrm{MnO}$ & 0.019 & 0.027 & 0.01 & 0.02 & 0.02 & 0.04 & 0.05 & 0.09 \\
\hline $\mathrm{MgO}$ & 0.07 & 0.06 & 0.11 & 0.05 & 0.17 & 0.05 & 0.07 & 0.09 \\
\hline $\mathrm{CaO}$ & 0.52 & 0.51 & 0.53 & 0.23 & 0.68 & 0.27 & 0.64 & 0.38 \\
\hline $\mathrm{Na}_{2} \mathrm{O}$ & 3.53 & 3.3 & 3.53 & 4.24 & 3.84 & 3.45 & 3.49 & 4.83 \\
\hline $\mathrm{K}_{2} \mathrm{O}$ & 4.86 & 4.45 & 4.55 & 5.48 & 4.96 & 5.22 & 4.73 & 2.39 \\
\hline $\mathrm{P}_{2} \mathrm{O}_{5}$ & 0.03 & 0.02 & 0.02 & 0.02 & 0.07 & 0.03 & 0.011 & 0.015 \\
\hline LOI & 0.13 & 0.18 & 0.74 & 0.11 & 1.26 & 0.54 & 0.87 & 1.95 \\
\hline B & - & - & 38 & 35 & 9 & 10 & - & - \\
\hline $\mathrm{F}$ & - & - & 2900 & 3557 & 560 & 2000 & 5100 & 7900 \\
\hline $\mathrm{Li}$ & - & - & 160 & 363 & 95 & 364 & 98 & 384 \\
\hline $\mathrm{Rb}$ & 322 & 314 & 594 & 750 & 290 & 860 & 802 & 1440 \\
\hline Cs & 8.9 & 13.5 & 35 & 41 & 30 & 51 & - & - \\
\hline $\mathrm{Sr}$ & 21 & 14 & 25 & 6 & 152 & 7 & 13 & 72 \\
\hline $\mathrm{Ba}$ & 56 & 50 & 293 & 45 & 280 & 8 & - & - \\
\hline $\mathrm{Zr}$ & 93 & 94 & 102 & 39 & 86 & 157 & 124 & 44 \\
\hline Sn & 2 & 4 & 18 & 8 & 3 & 8 & - & - \\
\hline $\mathrm{Pb}$ & 33 & 32 & 39 & 48 & 30 & 41 & - & - \\
\hline $\mathrm{Bi}$ & $<0.1$ & 0.1 & 4 & 13 & 2 & 7 & - & - \\
\hline $\mathrm{Nb}$ & 15.8 & 14.3 & 46 & 54 & 13 & 20 & 52 & 109 \\
\hline $\mathrm{Ta}$ & 2.06 & 2.8 & 9 & 14 & 3 & 10 & 7 & 52 \\
\hline W & $<0.5$ & 1.5 & 26 & 53 & 7 & 30 & 12 & 13 \\
\hline Th & 32.1 & 32.6 & 19 & 12 & 8 & 29 & 58 & 15 \\
\hline $\mathrm{Y}$ & 30.8 & 75 & 100 & 64 & 33 & 29 & 103 & 7.5 \\
\hline $\mathrm{Ce}$ & 67.4 & 48.2 & 80 & 68 & 70 & 6 & 83 & 13.5 \\
\hline
\end{tabular}

The content of oxides is given in wt.\%, trace elements in ppm. Hereinafter, a dash (-) indicates cases when an analysis on the particular element is not performed.

(a)

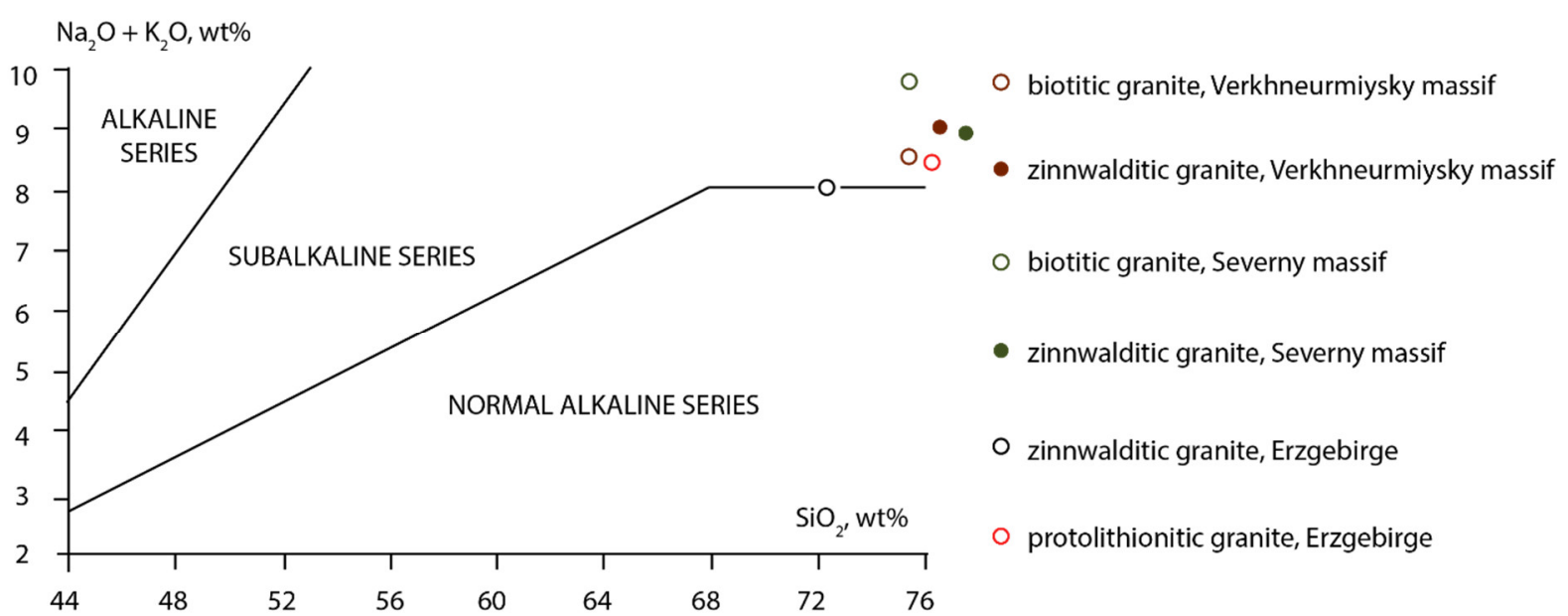

Figure 3. Cont. 
(b)

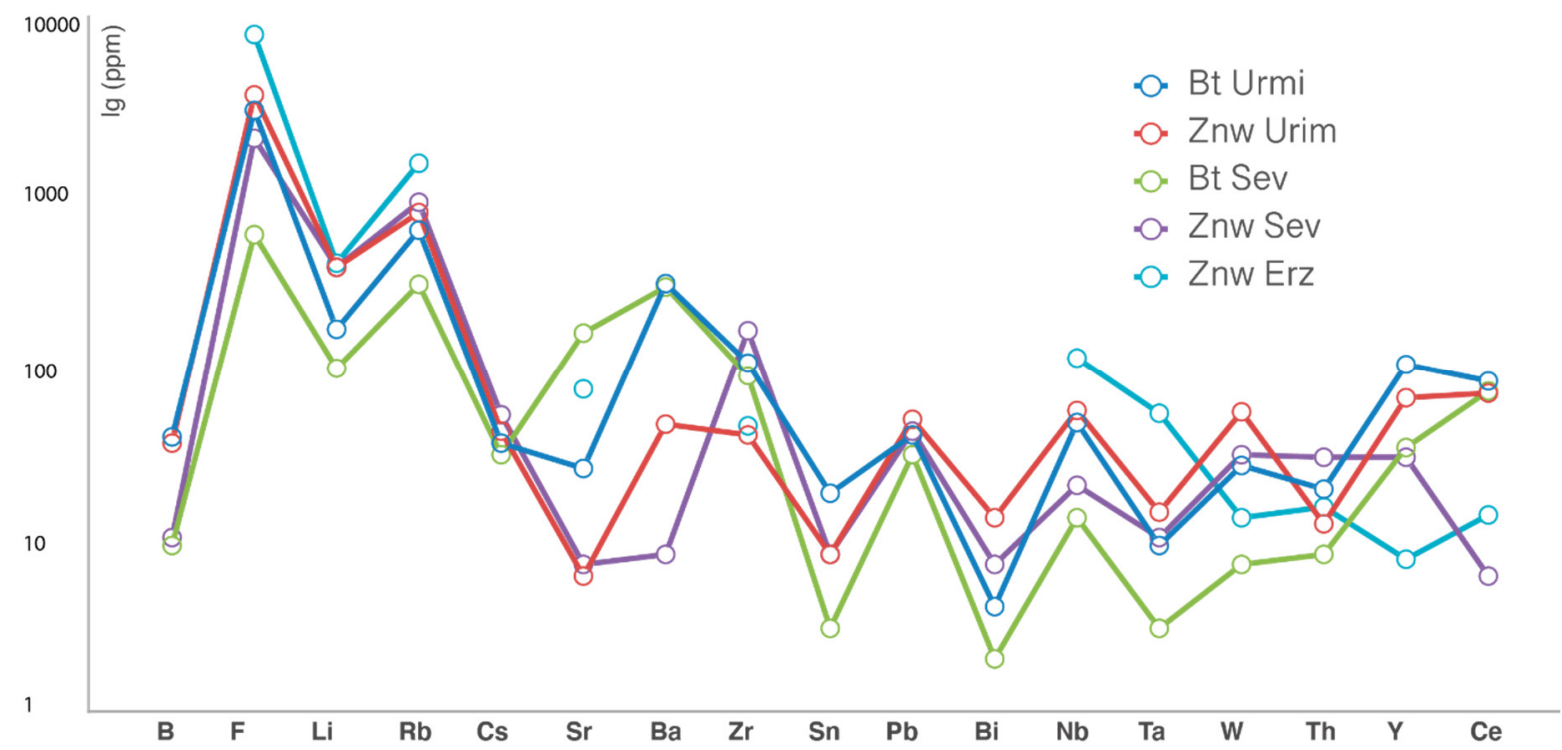

Figure 3. (a) $\left(\mathrm{Na}_{2} \mathrm{O}+\mathrm{K}_{2} \mathrm{O}\right) / \mathrm{SiO}_{2}$ values for Verkhneurmiysky granitoids on the Frost diagram [16]; (b) Spectra of trace elements in biotite (Bt) and zinnwaldite (Znw) granites of Verkhneurmiysky massif (Urmi), Severny massif (Sev), and Erzgebirge (Erz).

\section{Materials and Methods}

This work is based on the samples collected by the staff of the Mineralogical Department (Saint Petersburg Mining University) during the fieldwork from 1987 to 1990, headed by Yu.B. Marin and focused on the special mapping of the Verkhneurmiysky ore cluster. We studied 13 bulk samples and the corresponding thin sections, zircon single fraction from 8 samples of biotite granites (more than 555 grains), and 5 samples of zinnwaldite Li-F granites (460 grains). The studies were conducted in the laboratories of the Mining University [18-20], the Russian Geological Research Institute (VSEGEI), the Institute of Precambrian Geology and Geochronology, the Russian Academy of Sciences (Saint Petersburg, Russia), and the Institute of Mineralogy, TU Bergakademie Freiberg (Freiberg, Germany) (Table 2).

The zircon extraction was made according to the following method: crushing $(-0.5$; $-0.4 ;-0.315 ;-0.25) \rightarrow$ elutriation, drying $\rightarrow$ electromagnetic separation $\rightarrow$ extraction of non-electromagnetic fraction $\rightarrow \mathrm{CHBr}_{3}$ bromoform (density of $2.899 \mathrm{~g} / \mathrm{cm}^{3}$ at $15^{\circ} \mathrm{C}$ ) $\rightarrow$ heavy fraction (accessory minerals) $\rightarrow$ methylene iodide $\mathrm{CH}_{2} \mathrm{~J}_{2}$ (density $3.28 \mathrm{~g} / \mathrm{cm}^{3}$ ) $\rightarrow$ heavy fraction (zircon, monazite) $\rightarrow$ electromagnetic separation $\rightarrow$ extraction of nonelectromagnetic zircon-bearing fraction. The final stage of sample preparation was the zircon handpicking from the non-electromagnetic heavy fraction of each sample. We used JSM-6460LV (Oxford) to get approximately 80 back-scattered electrones (BSE) images of zircon grains and to perform a wavelength-dispersive X-ray (WDX) analysis of zircon composition in thin sections of biotite granite ( 35 grains $/ 66$ points) and zinnwaldite granite (40 grains/167 points).

To study the morphology and surfaces of zircon faces, 118 grains were applied to electrically conductive tape with subsequent conductive film deposition. They were studied in the laboratory of the Geological Institute of the TU Bergakademie Freiberg on a scanning electron microscope JEOL JSM-7001F. The SE images were obtained with the following parameters: accelerating voltage $-15 \mathrm{kV}$, probe current $-20 \mathrm{pA}$, resolution- $-3.0 \mathrm{~nm}$; BSE imaging was carried out under accelerating voltage of $20 \mathrm{kV}$ and probe current of $14 \mathrm{pA}$. The analyzed crystals were cleaned, impregnated into epoxy resin, and polished to study grain inner structure in BSE and CL. 
Table 2. The list of analyzed granite samples and extracted zircons, indicating the methods used and the corresponding number of measurements: OM—optical microscopy of granites in thin sections and extracted zircon grains, SEM—scanning electron microscopy (JSM-6460LV, Saint Petersburg, Russia) includes BSE imaging, WDX analysis of zircon and neighboring minerals in thin sections; SEM *-scanning electron microscopy (JEOL JSM-7001F, Freiberg, Germany) includes SE imaging of extracted zircon grains, applied to electrically conductive tape, to study the surface of crystal faces and BSE imaging of zircon grains, impregnated into epoxy resin and polished, to study the inner structure; SIMS-secondary ion mass spectrometry (Cameca IMS-4f, Yaroslavl, Russia) of zircon grains, impregnated into epoxy resin, to measure the trace element content (accompanied with BSE and cathodoluminescence (CL) imaging of zircon inner structure); Raman spectroscopy was applied to measure the degree of zircon crystallinity (Renishaw InVia Raman spectrometer, Saint Petersburg, Russia); $\mathrm{XRF}$ analysis of granite samples to determine the content of petrogenic elements and ICP-MS analysis for the petrogenic elements, as well as for a wide range of trace elements (Actlabs, Ancaster, ON, Canada).

\begin{tabular}{|c|c|c|c|}
\hline Sample No. & Granite Type & Number of Zircon Grains & Analysis \\
\hline 60136 & \multirow{8}{*}{$\begin{array}{l}\text { Biotite granite, Badzhal } \\
\text { complex }\end{array}$} & 130 & $\begin{array}{l}\text { OM; SEM (28 analysis); SEM * } \\
\text { (39 zircon grains); XRF, ICP-MS }\end{array}$ \\
\hline 82053 & & 60 & $\mathrm{OM}$ \\
\hline 85200 & & 75 & $\mathrm{OM}$ \\
\hline 85203 & & 75 & $\mathrm{OM}$ \\
\hline 97029 & & 90 & $\mathrm{OM}$ \\
\hline 60070 & & 50 & $\begin{array}{l}\text { OM; SEM (38 analysis); SEM * (19 grains); } \\
\text { SIMS (30 analysis / } 16 \text { grains); Raman } \\
\text { (20 spectra/10 grains) }\end{array}$ \\
\hline 60186 & & 35 & $\mathrm{OM}$ \\
\hline 60108 & & 40 & $\mathrm{OM}$ \\
\hline 60063 & \multirow{5}{*}{$\begin{array}{c}\text { Zinnwaldite granite, } \\
\text { Pravourmiysky complex }\end{array}$} & 35 & $\mathrm{OM}$ \\
\hline 60205 & & 200 & OM, SEM (100 analysis); XRF, ICP-MS \\
\hline 82073 & & 65 & OM; SEM (67 analysis), SEM * (38 grains); \\
\hline 04001 & & 70 & OM; SEM * (24 grains) \\
\hline 82240 & & 90 & $\begin{array}{c}\text { OM; SIMS (37 analysis/25 grains); Raman } \\
\text { (16 spectra/8 grains) }\end{array}$ \\
\hline
\end{tabular}

The analysis of the trace elements content in zircon (67 analytical points/41 grains) was carried out on the Cameca IMS-4f ion microprobe (Valiev Institute of Physics and Technology of RAS, Yaroslavl, Russia) using standard methods [21,22]. The ion beam diameter was not more than 15-20 $\mu \mathrm{m}$, the relative error for the majority of elements did not exceed $15 \%$, and the detection limit is $10 \mathrm{ppb}$ on average. We obtained data on the content of 11 lanthanides, $\mathrm{Li}, \mathrm{P}, \mathrm{Ca}, \mathrm{Ti}, \mathrm{Sr}, \mathrm{Y}, \mathrm{Nb}, \mathrm{Cs}, \mathrm{Ba}, \mathrm{Hf}, \mathrm{Th} \mathrm{U}, \mathrm{F}$, and $\mathrm{H}_{2} \mathrm{O}$, and calculated the most important geochemical parameters, including $\mathrm{Th} / \mathrm{U}$ ratio, Eu- and Ceanomalies, $\Sigma$ REE, $\Sigma$ LREE, $\Sigma$ HREE, and chondrite-normalized [23] LuN/LaN, LuN/GdN, and $\mathrm{SmN} / \mathrm{LaN}$ ratios.

A non-destructive Raman spectroscopy technique was applied to measure the degree of crystallinity of zircon. Raman spectra were collected by means of the Renishaw InVia Raman spectrometer installed in the Department of Mineralogy, Saint Petersburg Mining University, using an excitation wavelength of $785 \mathrm{~nm}$ (diode NIR laser) and a thermoelectrically cooled charge-coupled device (CCD) detector equipped with a $1200 \mathrm{~L} / \mathrm{mm}$ grating. The laser output power of $300 \mathrm{~mW}$ was reduced to $0.1 \%$ of the standard value, which is non-destructive to samples of interest. In each experiment, five scans were collected and averaged. The typical acquisition time was $20 \mathrm{~s}$. The theoretical diffraction-limited confocal-spot diameter of the laser beam at the sample surface was approximately $1.5 \mathrm{~mm}$ with a Leica $50 \times$ long-working-distance objective and a $10 \times$ ocular. Repeated acquisitions of the crystals using the highest magnification $(50 \times)$ were accumulated to improve 
the signal-to-noise ratio in the spectra. The Raman spectra of zircon from biotite granite (20 spectra/10 grains) and zinnwaldite granite (16 spectra/ 8 grains) were obtained from the analytical points of the preceding ion microprobe analysis of trace elements content. The spectra were recorded in a narrow range from 950 to $1050 \mathrm{~cm}^{-1}$, containing $v_{1}\left(975 \mathrm{~cm}^{-1}\right)$ and $v_{3}\left(1008 \mathrm{~cm}^{-1}\right)$ bands, which are responsible for symmetric and anti-symmetric stretching of the $\mathrm{SiO}_{4}$ group, respectively [24,25]. Spectra were calibrated using the $520.5 \mathrm{~cm}^{-1}$ line of a silicon wafer. Spectral manipulations such as smoothing (without baseline correction) and peak parameters recording were performed using the software package Wire 2.0.

No indications of surface damage and change of color by the laser radiation were observed during the sample checking after Raman measurements.

The bulk composition of granites was determined, using XRF analysis-for the petrogenic elements, and ICP-MS analysis for the petrogenic elements, as well as for a wide range of trace elements (Sc, Be, V, Cr, Co, Ni, Cu, Zn, Ga, Ge, As, Rb, Sr, Y, Zr, Nb, Mo, Ag, In, Sn, Sb, Cs, Ba, La, Ce, Pr, Nd, Sm, Eu, Gd, Tb, Dy, Ho, Er, Tm, Yb, Lu, Hf, Ta, W, Ti, Pb, $\mathrm{Bi}, \mathrm{Th}$, and $\mathrm{U}$ ), in the Actlabs laboratory (Ancaster, ON, Canada).

\section{Results and Discussion}

\subsection{Zircon Mineral Associations}

The set of Li-F granite accessory minerals and their determining role in the prospecting works are briefly discussed in Section 2.2. The geochemical evolution of the granitoid series of the Far East can also be traced in the evolution of the composition of typomorphic accessory minerals: zircon, ixiolite-(W), ferberite-( $\mathrm{Nb})$, allanite-(Y), and chernovite-( $(\mathrm{Y})$ [2] An example of an indicator accessory mineral coexisting with zircon is allanite, which changes from Ce and alumina-bearing type in the complex of early biotite leucogranites to Y-bearing ferriferous allanites in zinnwaldite granites (Figure 4) [2,26].

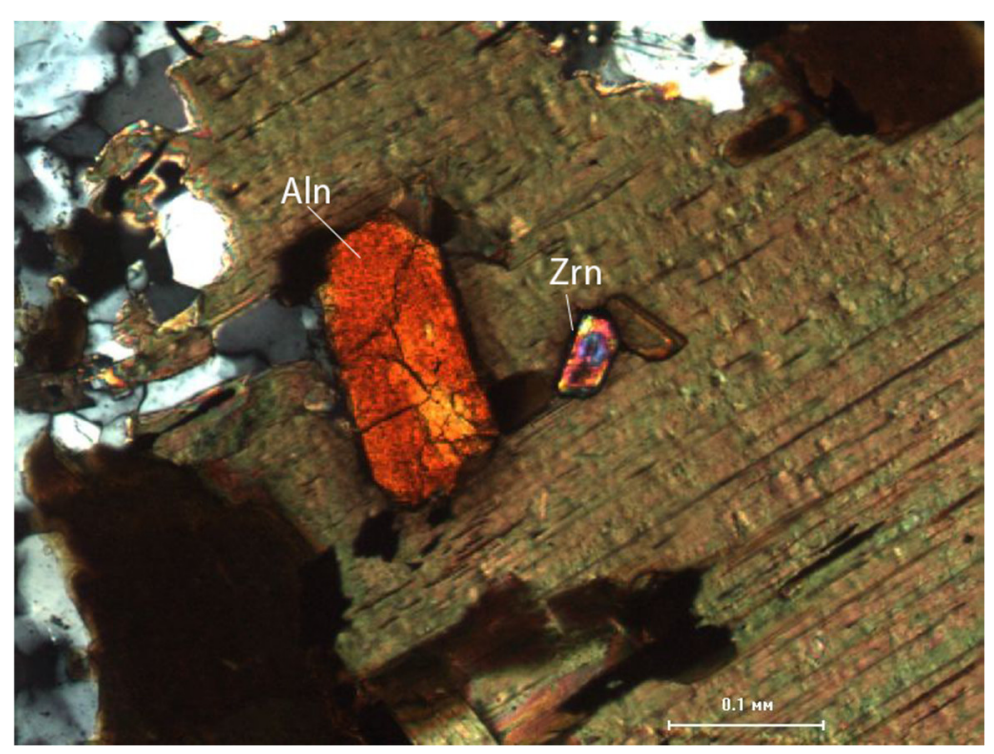

Figure 4. Accessory allanite (Aln) and zircon (Zrn) in zinnwaldite granite (sample 04001), nicols crossed.

The characteristic feature of slightly altered zircon from biotite granites (Zrn-Bt), usually located at the grain boundaries of rock-forming quartz and biotite crystals, is the formation of accretions and intergrowth with equal-sized and relatively small grains of xenotime. Xenotime forms short-prismatic crystals, euhedral grains and solid masses, with an average formula $\left(\mathrm{Y}_{0.71-0.76} \mathrm{Gd}_{0.02-0.03} \mathrm{Dy}_{0.06-0.08} \mathrm{Er}_{0.04} \mathrm{Yb}_{0.03-0.07}\right)\left[\mathrm{PO}_{4}\right]$ (Figure 5a-c). In addition, zircon grains contain rare inclusions of table apatite crystals (Figure $5 \mathrm{c}$ ). 


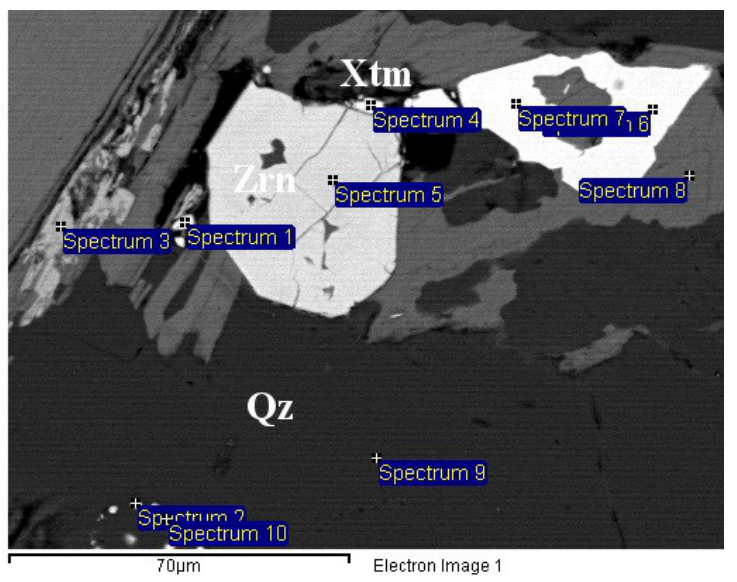

(a)

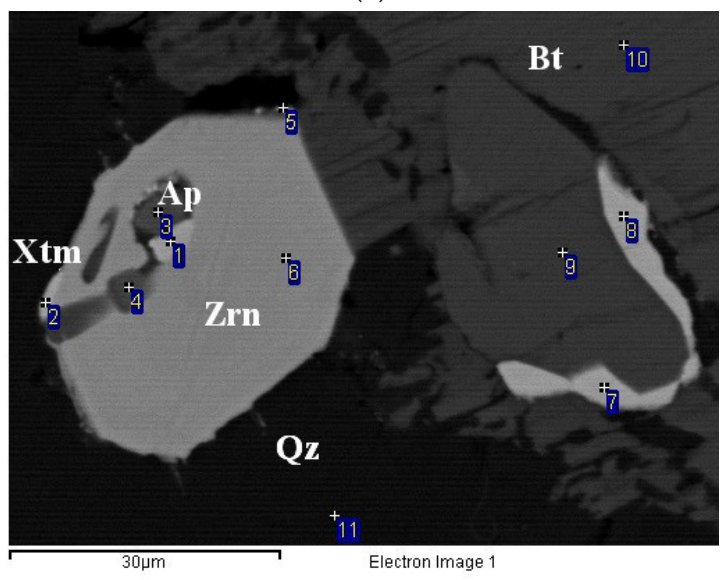

(c)
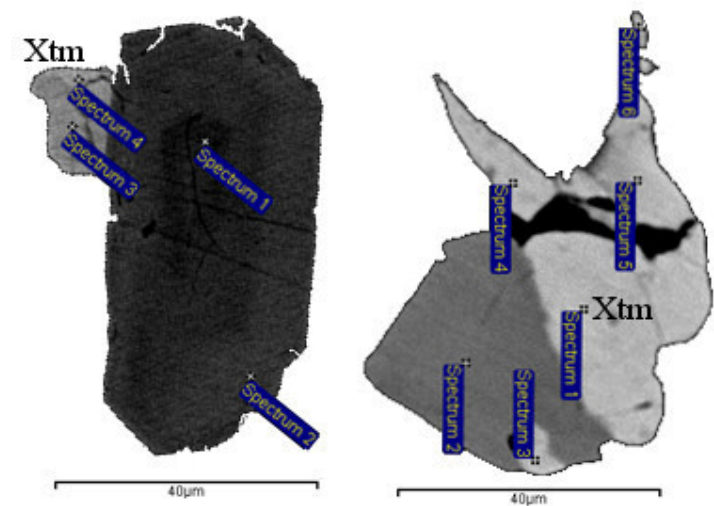

(b)

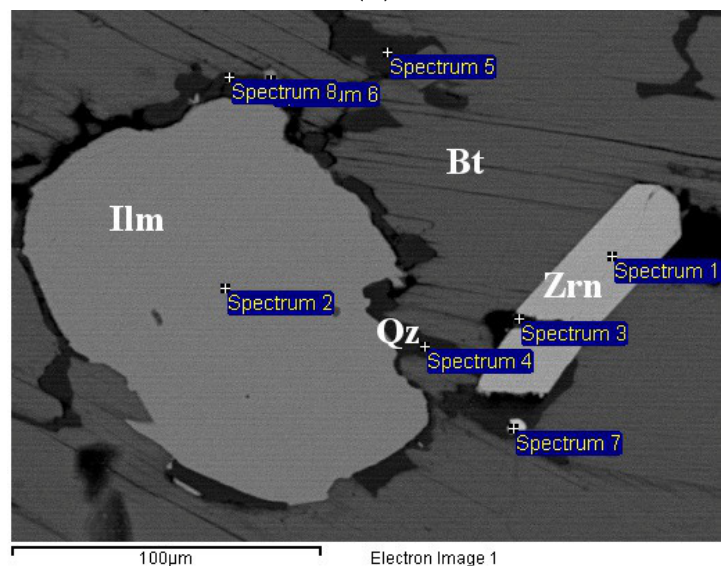

(d)

Figure 5. Associations of accessory zircon in biotite granite, BSE images: (a,b) zircon and xenotime intergrowth; (c) xenotime and apatite grains in zircon; (d) long-prismatic zircon and ilmenite in biotite.

There is a close association of long-prismatic zircon with tabular grains of ilmenite with quartz rims enclosed in biotite crystals. The characteristic feature of the titanium and iron oxide phase is the constant impurity of Mn (4.16-10.32\%) (Figure 5d).

Zircon from zinnwaldite granites Zrn-Znw forms extremely small grains (30-50 $\mu \mathrm{m})$ with varying alteration degrees and is located on the grain boundaries of anhedral microcline (Figure 6b,c), prismatic albite (Figure 6a-d), pea-shaped quartz (Figure 6c), as well as in small zinnwaldite nodules (Figure 6b) and inside zinnwaldite crystals (Figure 6e). Often there are intergrowths of anhedral spongy zircon with monazite of varying composition $\left(\mathrm{Ce}_{0.46-0.47} \mathrm{La}_{0.18-0.19} \mathrm{Nd}_{0.16-0.17} \mathrm{Th}_{0.04-0.12} \mathrm{Sm}_{0.01-0.02}\right)\left[\mathrm{PO}_{4}\right]$ with the same grain size and a lower degree of alteration (Figure $6 \mathrm{f}$ ).

Mica shows plastic deformations (Figure 6f), which are consistent with the concept of early syngenetic protoclase of rock-forming and accessory minerals of rare-metal granites associated with increased fluid pressure [10,27]. Zircon and xenotime occur together, both as the intergrowth of weakly altered grains of both minerals and as xenotime microinclusions in strongly altered zircon grains formed in the recrystallization and/or dissolution-precipitation processes (Figure 7a,b).

Xenotime crystals included in zircon show partial substitution with chernovite that forms an almost continuous xenotime-chernovite isomorphic series (Figure 7c). The chernovite formation is associated with the autometasomatic alterations in rare-metal granites which took place under the As-bearing fluids, characteristic to the rare-metal magma, enriched with both lithophile (W, Nb, Y, REE, Th, etc.) and chalcophile elements 
(As, S, Sn, Cu, Bi, etc.) $[14,28]$. The appearance of the As-phases in Zrn-Znw is consistent with the sharply increased content of As in zinnwaldite granites.

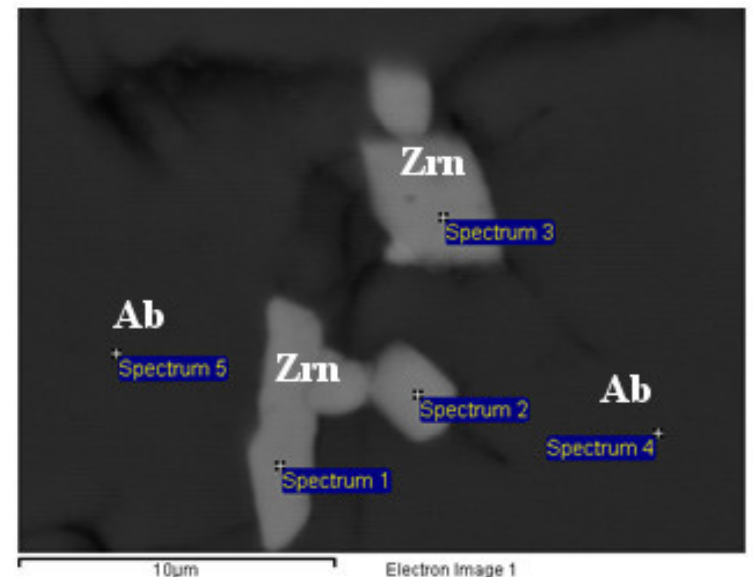

(a)

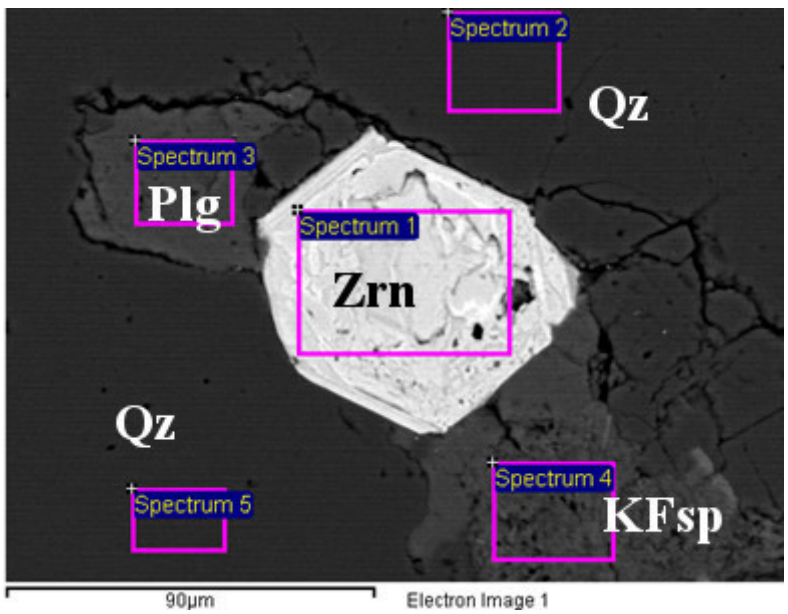

(c)

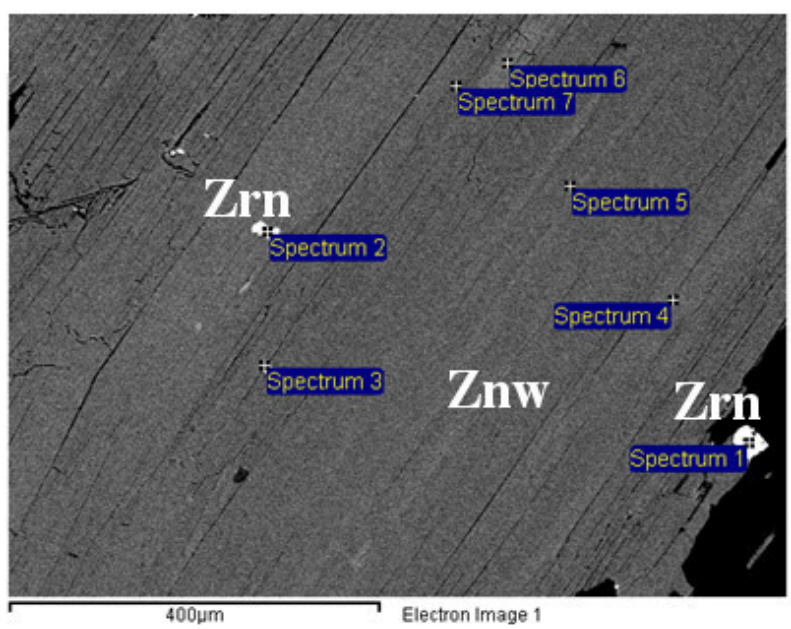

(e)

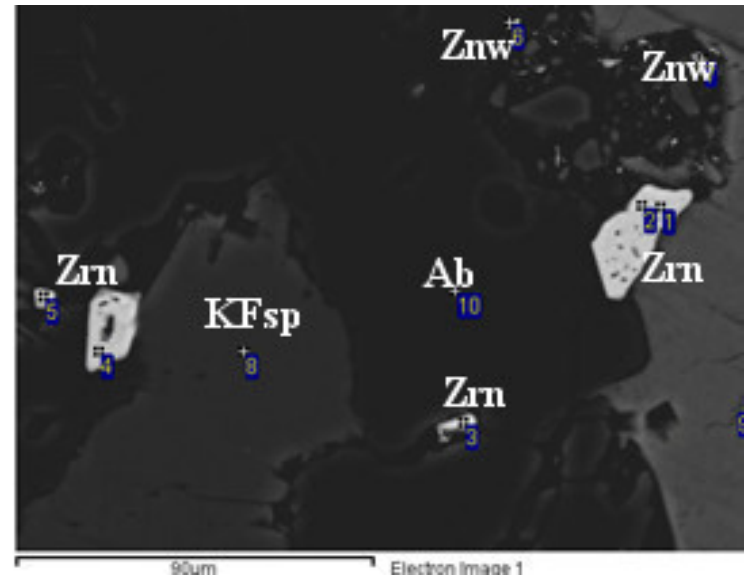

(b)

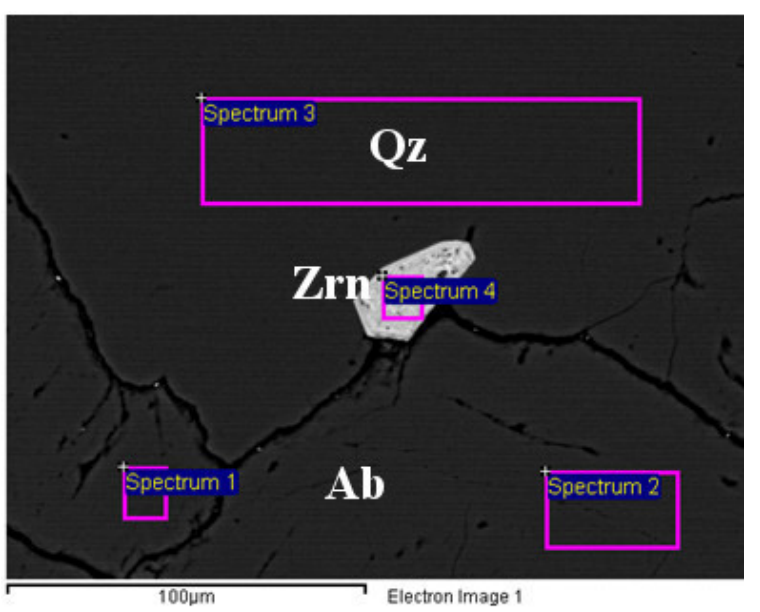

(d)

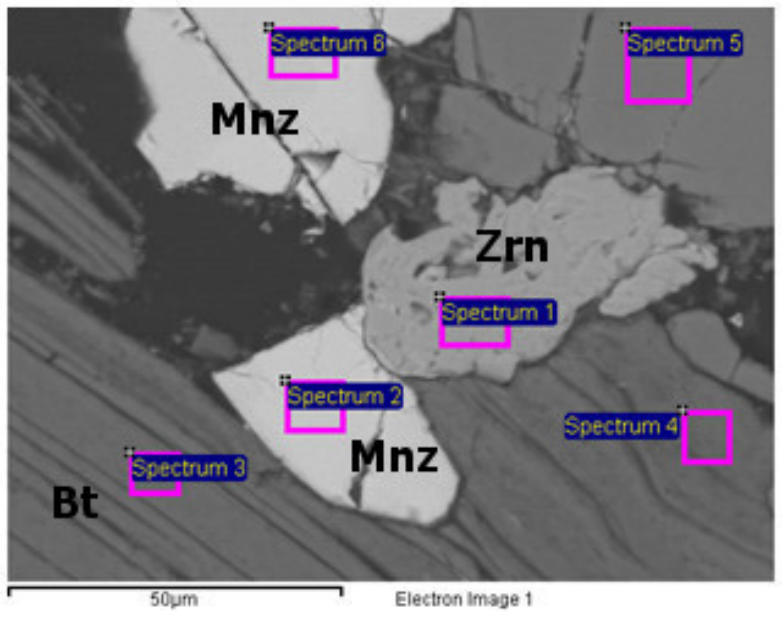

(f)

Figure 6. Accessociation of zircon in zinnwaldite granite, BSE images: (a) anhedral zircon grains in albite; (b) spongy zircon in zinnwaldite nodules; (c,d) euhedral zircon grains at the borders of rock-forming minerals; (e) zircon in zinnwaldite; (f) anhedral zircon intergrowth with monazite at the border of deformed biotite crystal. 


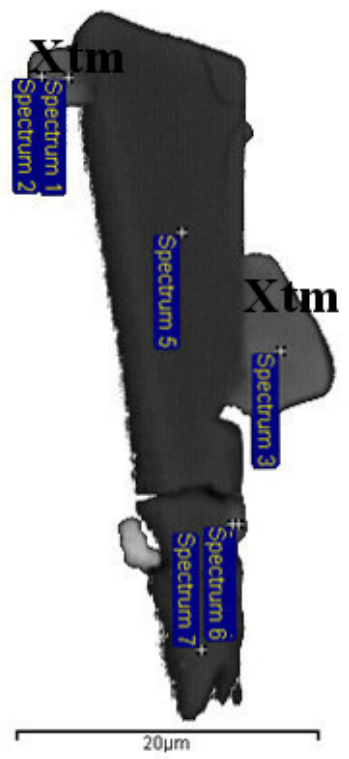

(a)

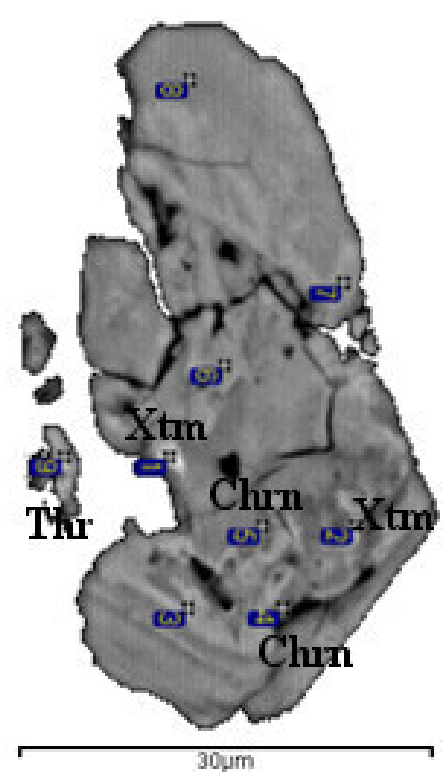

(c)

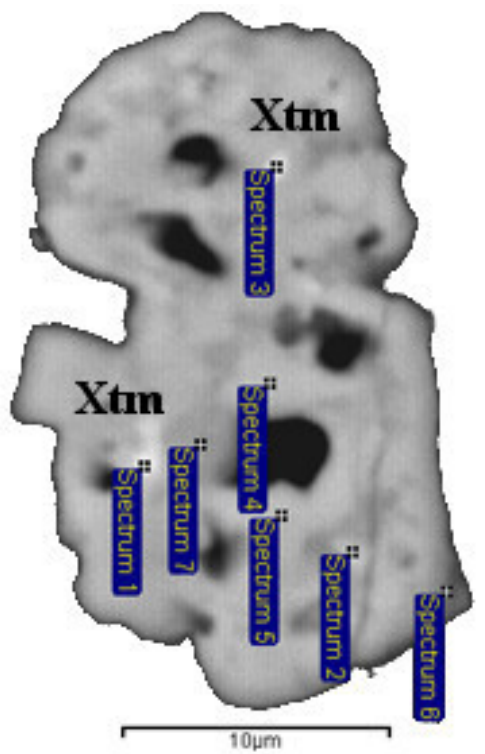

(b)

Figure 7. Associations of zircon from zinnwaldite granites with phosphate phases: (a) intergrowth of slightly altered long-prism zircon and xenotime; (b) xenotime phases in recrystallized zones of spongy zircon; (c) xenotime and chernovite phases in significantly altered zircon.

\subsection{Zircon Morphology}

Zircon morphology can record genetic information about changes in the crystallization parameters, which makes it reasonable to study morphological and anatomical features of both microcrystals and intergrowth of zircon.

Primary microscopic study of 13 samples (60-200 grains/samples) allowed identifying at least two types of zircon grains in all samples:

- The first type is represented by the relatively short prisms, brown and honey-colored, semi-transparent idiomorphic crystals. Some grains have rims, which are cleaner, lighter, and have a lower refractive index. Such rims may indicate postmagmatic changes or at least a significant interruption in zircon growth and a change in physical and chemical growth conditions. Almost all grains have metamict cores and partial amorphization in the near-core regions (Figure 8a,b); 
- The second type includes virtually colorless, long-prismatic grains without metamict cores; however, mineral and melt inclusions are present in considerable quantities (Figure 8c,d).

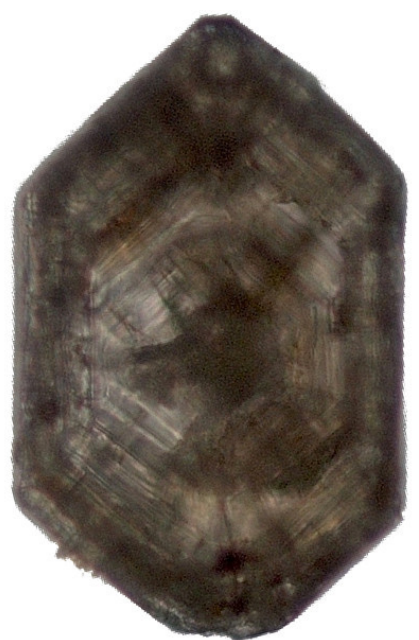

(a)

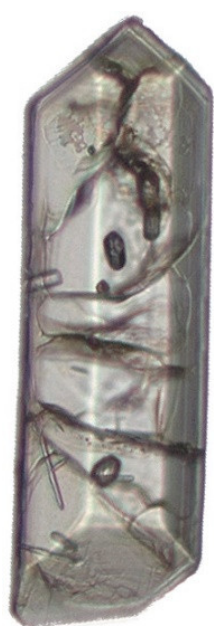

(c)

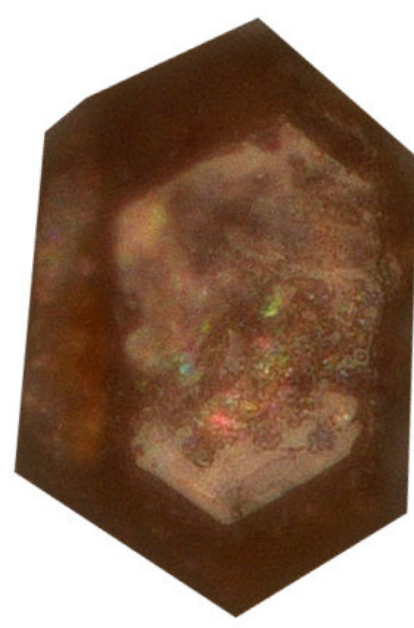

(b)

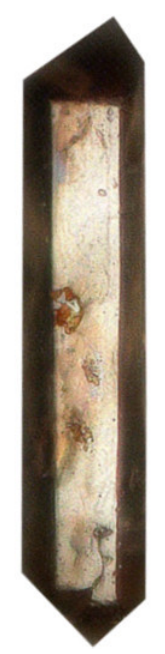

(d)

Figure 8. (a,b) Short-prismatic, honey-brown euhedral zircon grain of the first type; (c,d) Colorless, long-prismatic zircon grain of the second type.

The division into long- and short-prismatic zircon varieties is based on the median elongation value of 1.92 for biotite granites, and a median elongation value of 1.55 for zinnwaldite granites.

This approach partially solves the question of adequate interpretation of morphotype distribution in the Pupin diagram [29], since the entire zircon population, can record only the general trend of all morphotypes predominance, while the division into varieties records the stages of zircon evolution even within a single sample. The result of a statistically valid division of the zircon sample into short- and long-prismatic varieties is the presence of two different evolutionary trends. The trend of the long-prismatic zircon coincides with the general trend of the entire sample, while the evolution curve of the short-prismatic variety is directed towards the lower lines of the Pupin diagrams (Figure 9). 


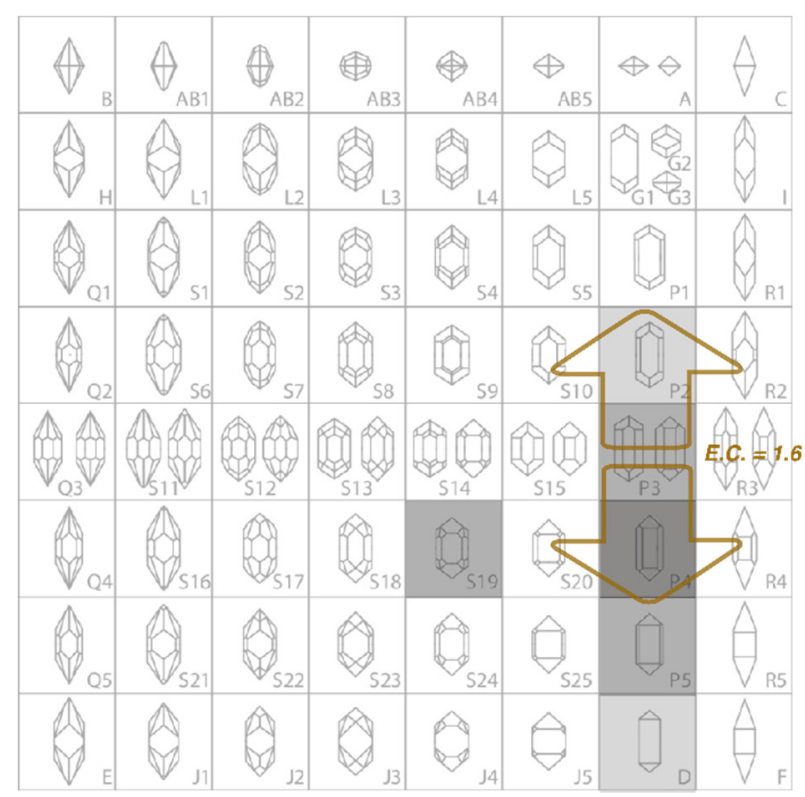

(a)

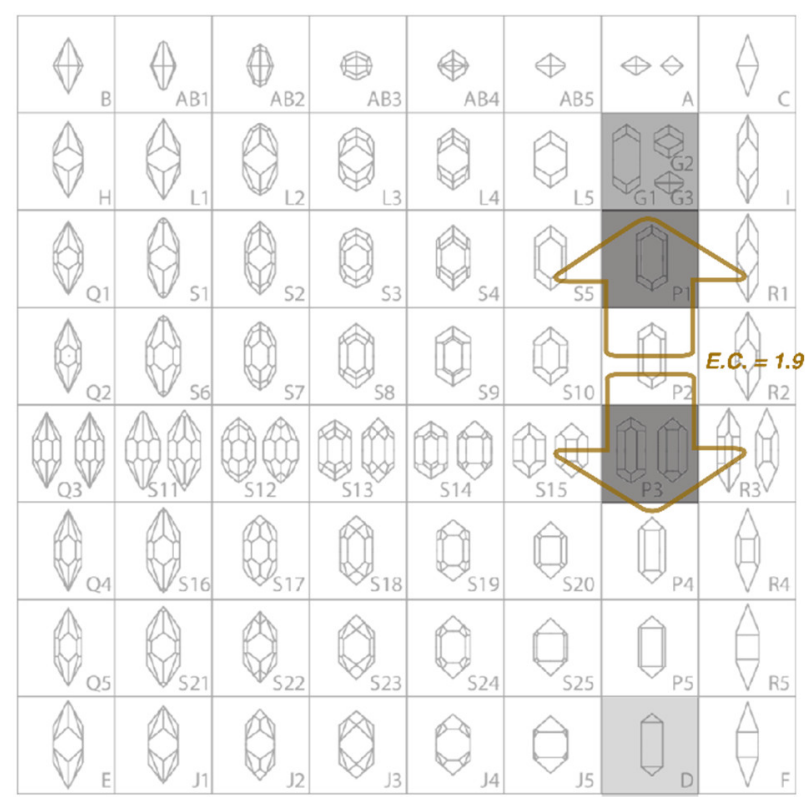

(b)

Figure 9. Pupin diagram for: (a) Zrn-Bt and (b) Zrn-Znw. The tone gradient from black to light grey indicates the degree of abundance (from maximum to minimum, respectively) of zircon morphotypes in each sample. The contour arrows show that short-prismatic zircon tends to the upper field of the diagram, and long-prismatic zircon-to the lower one.

The two distinct zircon morphotypes are taken as evidence of the fluid phase evaporation from the melt [30], the formation of two zircon varieties within a single sample may be related to the F-containing fluids, which separated during emanation differentiation and affected already crystallized rocks. The scattering of the Zrn-Bt morphotypes along the horizontal axis demonstrates breaking points in its evolution and characterizes the heterogeneity of the melt. The relatively low intended temperature of Zrn-Znw formation indicates the fluid saturation of the melt and indirectly confirms the transfer of lithium and tin in the composition of F-complexes. Thus, the most abundant Zrn-Bt and Zrn-Znw morphotypes are P4 and P1/P3, respectively (Figure 9).

\subsection{SE and BSE Zircon Images}

The electron microscopy study of zircon confirmed the presence of short- and longprismatic varieties in both studied granitoids and allowed the tracing of some genetic features of the formation processes.

Zircon from biotite granites (Zrn-Bt) is enriched with impurities, shows partially or completely altered cores of short-prismatic crystals with preserved oscillatory zoning, saturated with micropores and microinclusions of coffinite-thorite, monazite-cheralite phases and dark (in BSE) rims around the central zones (Figure 10a,b).

The formation of such a spongy texture with an abundance of mineral inclusions is a consequence of the dissolution-precipitation of zircon enriched with impurities under the influence of fluids, seeping through the numerous fissures formed during crystal growth [31-35]. In contrast, in the long-prismatic zircon Zrn-Bt, the cores have less impurities and have an elongated habit with reduced dipyramids and weak zoning (Figure 10c,d). Both types of Zrn-Bt have similar corrosion of the grain edges, presence of thin zones with wavy edges, and concentric heterometry-induced cracks that intersect the primary growth zoning. 


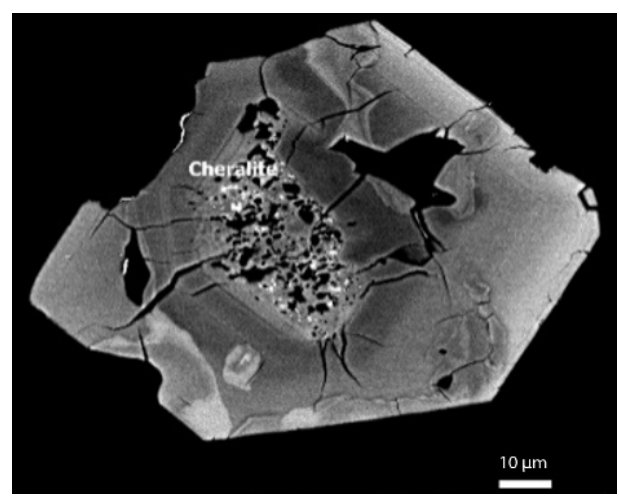

(a)

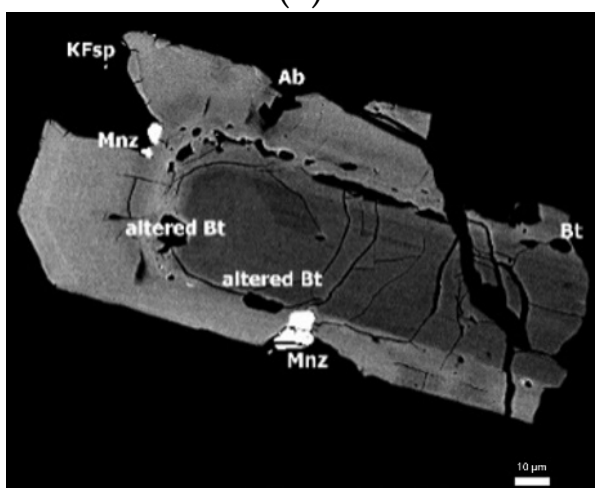

(c)

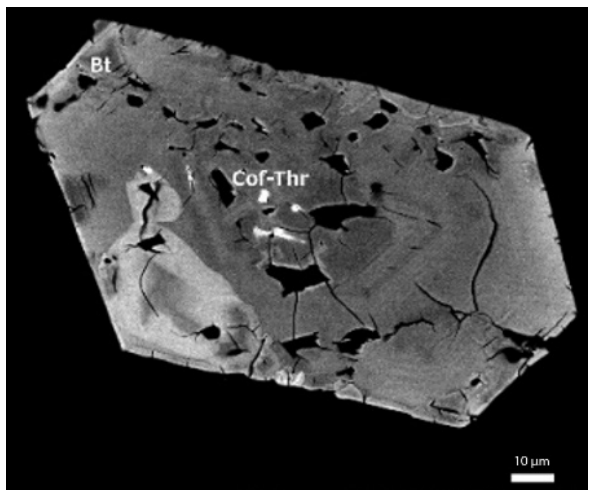

(b)

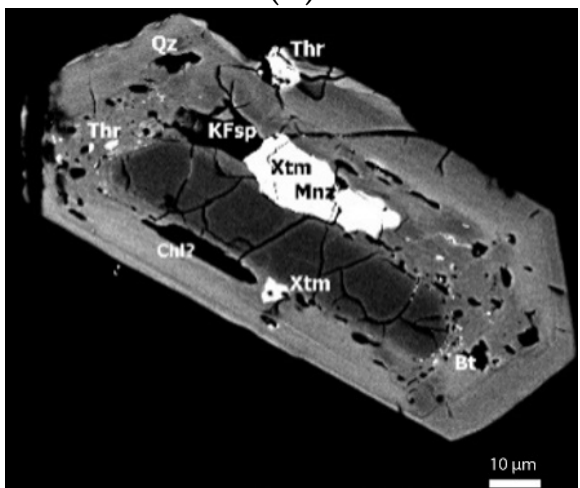

(d)

Figure 10. BSE images of short-prismatic (elongation coefficient $<1.5$ ) long-prismatic (elongation coefficient > 1.5) varieties of Zrn-Bt: (a) the completely recrystallized central part, the micro inclusions of the monazite-cheralite phases, wavy boundaries of the altered zones cross the initial fine zoning; (b) the completely recrystallized central domain and rim form a common area crossing the primary fine zoning, a concentric system of fractures elongated from core to rim; (c) zone of secondary alterations around impurity depleted core, monazite inclusions, depleting zircon growth; (d) cracked core with weakly zoning surrounded with wide $(11-15 \mu \mathrm{m})$ porous zone of secondary alterations with inclusions of xenotime and monazite, potassium feldspar, thorite, biotite, and quartz.

Morphological and inner texture features of zircon in biotite granites allowed assuming some stages of mineral formation and transformation, namely: alkalinity increase in the crystallization medium (dipyramid facets growth) at the rims growth and active influence of the fluid phase at the final magmatic stages of the massif formation (similar nature of secondary alterations in the short and long-prismatic variety of zircon Zrn-Bt). Zircon Zrn-Znw from Li-F zinnwaldite granites does not form parallel intergrowth but is characterized by a complex internal structure and intergrowth with micro-spherulitic aggregates of the chernovite $\mathrm{Y}\left[\mathrm{AsO}_{4}\right]$-xenotime $\mathrm{Y}\left[\mathrm{PO}_{4}\right]$ series (Figure 11).

It should be noted that the formation of similar chernovite aggregates in Li-F granites of Zinnwald is connected with the arsenic supply at the oxidation stage [36], and in A-type granites (Zinnowitz-Rejkovo) post-magmatic fluids are considered as a unique source of arsenic [37]. Thus, the nature of such intergrowth is a strong argument for autometasomatic alterations in rare-metal Li-F granites [10,28]. 


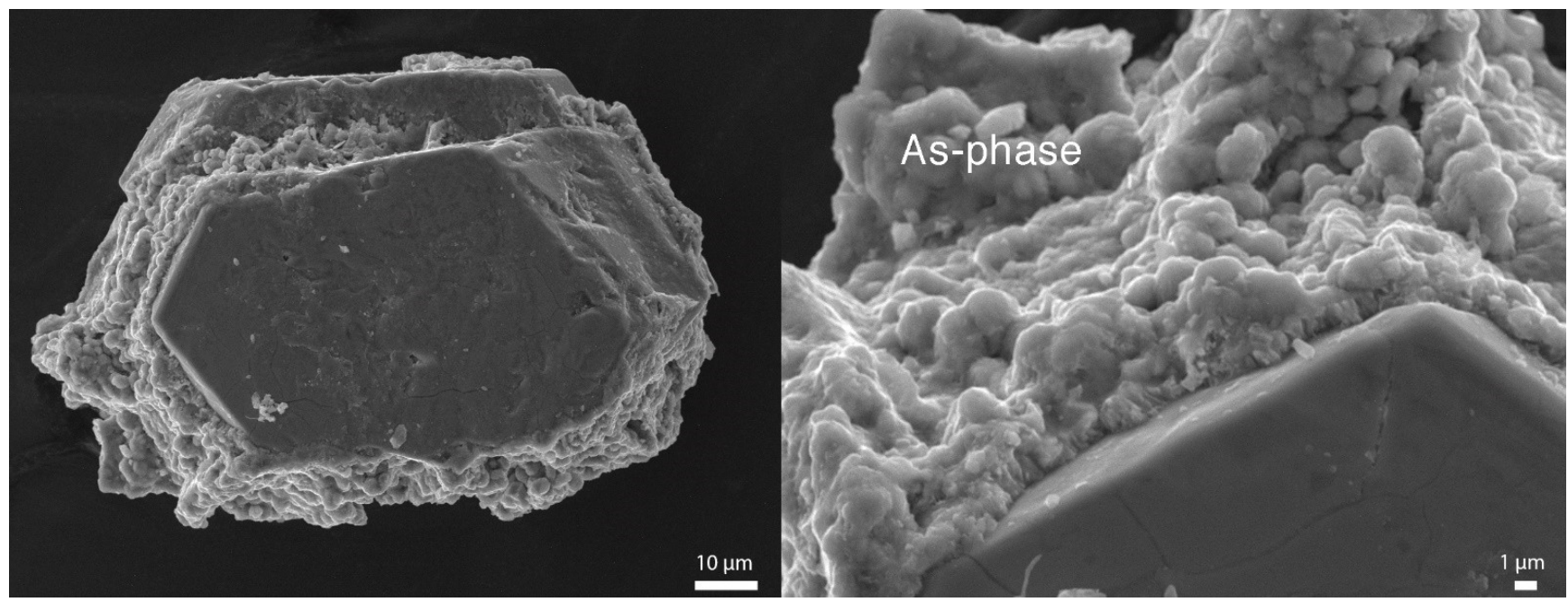

Figure 11. SE image of Zrn-Znw covered with micro spherolite aggregates of chernovite $\mathrm{Y}\left[\mathrm{AsO}_{4}\right]$ —xenotime $\mathrm{Y}\left[\mathrm{PO}_{4}\right]$ phases.

Crystals of the long-prismatic Zrn-Znw variety are characterized by spotty zoning (Figure 12b) with rare remains of the primary oscillatory one, obscured by an uneven distribution of secondary blocks of trace elements concentration/depletion [2,38]; increased rims brightness in BSE images, indicating enrichment with heavy elements; increased amount and irregular distribution of cracks. Postmagmatic alterations of long-prismatic Zrn-Znw under the influence of the fluid phase are evidenced by superimposed wavy zoning and chains, formed after gas-liquid inclusions decrepitation, and crossing the primary growth zoning (Figure 12a).

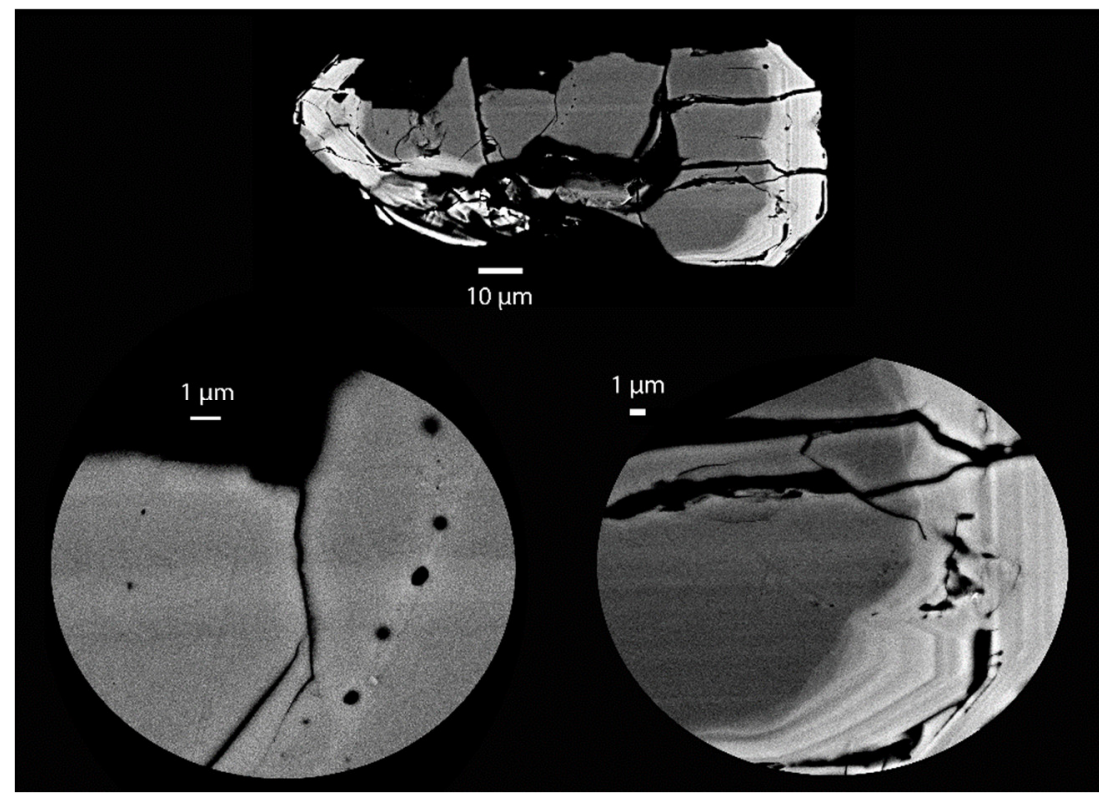

(a)

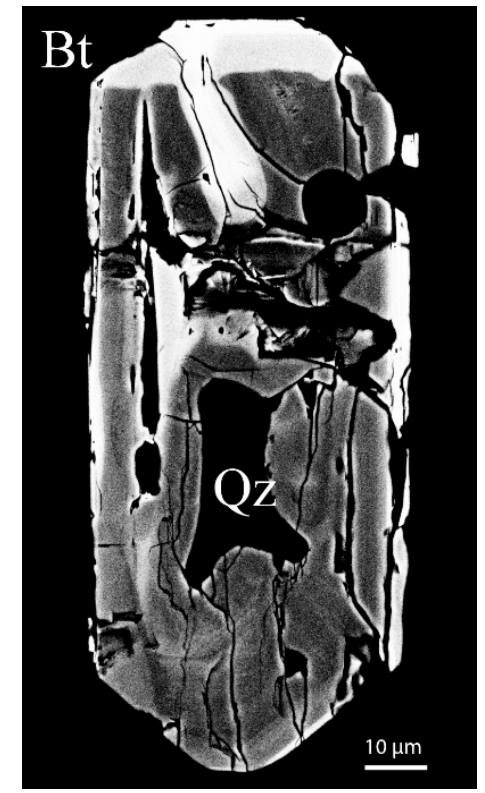

(b)

Figure 12. (a) Long-prismatic Zrn-Znw crystal with a chain of open gas-liquid inclusions (left) and primary oscillatory and superimposed wave-shaped zoning (right); (b) BSE image of the long-prismatic Zrn-Znw crystals demonstrating the spotty zoning and inclusions of rock-forming biotite $(\mathrm{Bt})$ and quartz $(\mathrm{Qz})$. 
Short-prismatic Zrn-Znw variety shows the most complex inner structure: the core/rim boundaries and the primary growth zoning are obscured and give way to the secondary wavy zones and homogeneous blocks with soft edges; pores of different sizes are widespread and concentrate numerous inclusions of thorite, xenotime, chernovite, and monazite.

Distinctive features of the short-prismatic Zrn-Znw are the maximum content of heavy trace elements (relatively bright BSE images), as well as the secondary wavy zoning, porosity, and abundance of inclusions, which occupy a significantly larger grain area (in the section) than similar alteration zones in zircon from biotite granites. Secondary alterations can be seen on the surface of Zrn-Znw faces as the abundance of caverns and dissolution relief.

Thus, the contrast of morphological features of both zircon types from the initial (Zrn$\mathrm{Bt}$ ) and final (Zrn-Znw) granite series is an important additional tool to reveal rare-metal Li-F granites within the Verkhneurmiysky massif. The oscillatory zoning of Zrn-Bt reflects the long path of water-poor magma evolution, which is able to travel long distances; the spotty zoning and increased porosity of Zrn-Znw indicate less stable growth conditions, increased activity of the fluid phase, and lattice defects due to secondary alterations and formation of mineral inclusions (Figure 13).

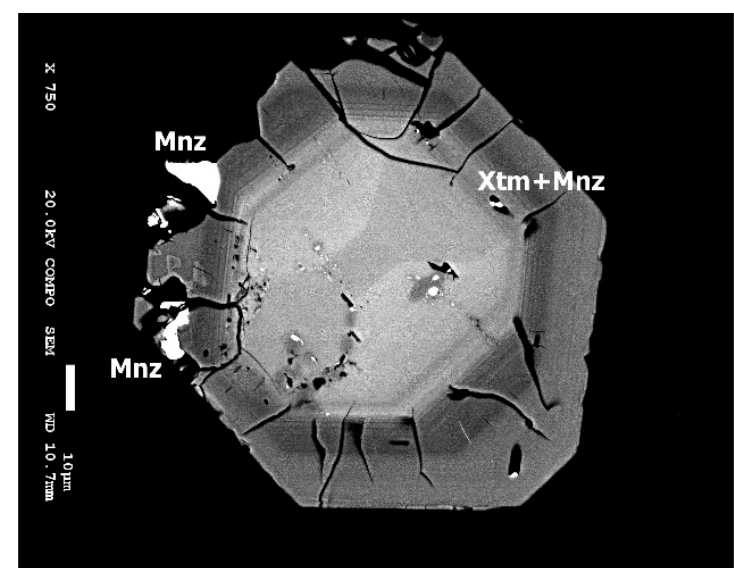

Zrn-Bt

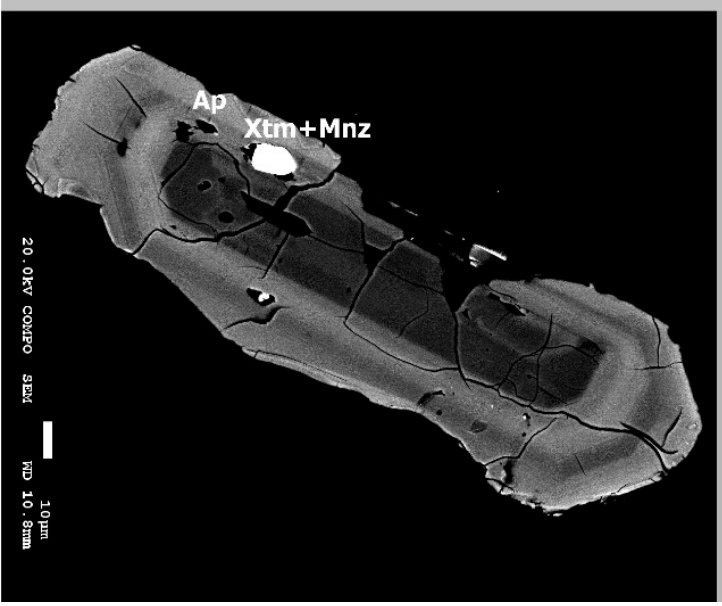

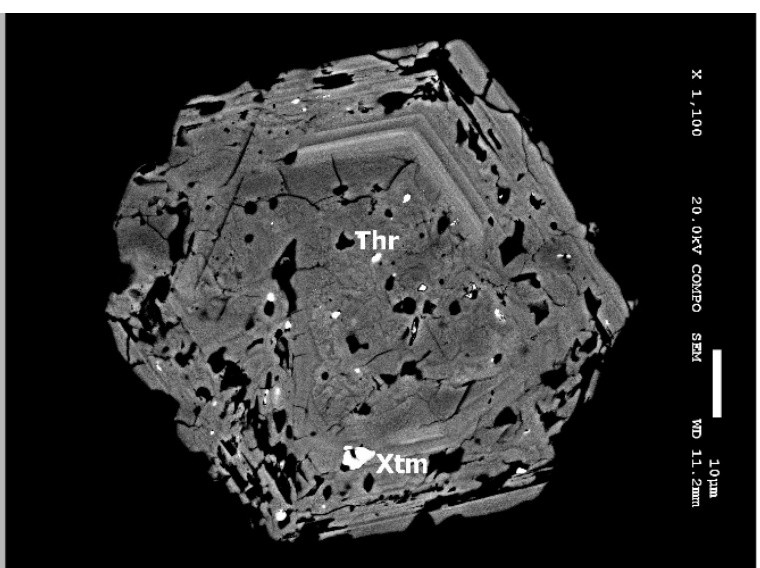

Zrn-Znw

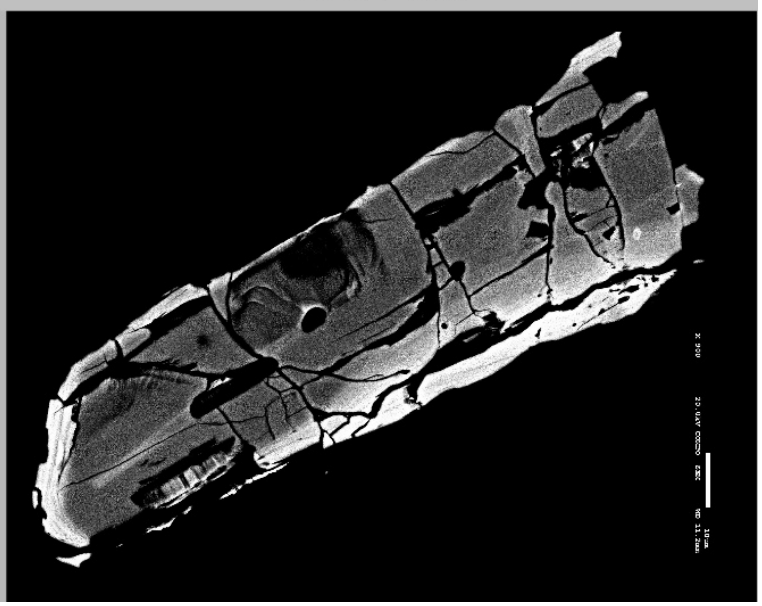

Figure 13. The most typical images showing the differences in the internal structure of short and long-prismatic varieties of zircon from biotite and Li-F zinnwaldite granites.

\subsection{Trace-Element Composition of Zircon}

Before proceeding to the discussion of the elemental composition of the studied zircon, it is necessary to make a brief comparison with zircon from granites of similar genesis from different geographical regions, for example: biotite and Li-F granites of the Severny massif 
(Chukotka) [2], Li-F granites of Zinnwald deposit (Germany) $[39,40]$ and zinnwaldite granites of Mole massif (Australia) [41] (Tables 3 and 4).

Table 3. Composition of zircon (ppm) from biotite leucogranites of the Verkhneurmisky massif, Amur region (median and quartiles calculated from ion probe data), and the Severny massif, Chukotka [2].

\begin{tabular}{|c|c|c|c|c|c|c|c|c|c|c|c|c|}
\hline \multicolumn{13}{|c|}{ Zircon from Biotite Granites } \\
\hline \multirow{3}{*}{ Element } & \multicolumn{6}{|c|}{ Verkhneurmisky Massif Amur Region } & \multicolumn{6}{|c|}{ Severny Massif Chukotka } \\
\hline & \multicolumn{3}{|c|}{ Core } & \multicolumn{3}{|c|}{ Rim } & & & & & & \\
\hline & $\begin{array}{c}\text { Quartile } \\
50 \%\end{array}$ & $\begin{array}{c}\text { Quartile } \\
75 \%\end{array}$ & $\begin{array}{c}\text { Quartile } \\
25 \%\end{array}$ & $\begin{array}{c}\text { Quartile } \\
50 \%\end{array}$ & $\begin{array}{c}\text { Quartile } \\
75 \%\end{array}$ & $\begin{array}{c}\text { Quartile } \\
25 \%\end{array}$ & & & & & & \\
\hline $\mathrm{Li}$ & 1.02 & 1.91 & 0.59 & 1.82 & 2.06 & 1.59 & 0.1 & 0.1 & 0.05 & 0.57 & 0.1 & 2.38 \\
\hline $\mathrm{P}$ & 421 & 706 & 289 & 893 & 1077 & 778 & - & - & - & - & - & - \\
\hline $\mathrm{Ca}$ & 11.1 & 45.6 & 8.05 & 3.94 & 7.49 & 2.29 & 0.81 & 0.72 & 0.55 & 132 & 0.38 & 5.99 \\
\hline $\mathrm{Ti}$ & 36.6 & 79.5 & 24.6 & 7.10 & 22.5 & 3.34 & 10.7 & 9.04 & 21.3 & 5.63 & 17.5 & 7.46 \\
\hline $\mathrm{Sr}$ & 1.32 & 1.79 & 0.97 & 2.04 & 2.21 & 1.83 & 0.63 & 0.67 & 0.6 & 1.09 & 0.72 & 1.27 \\
\hline $\mathrm{Y}$ & 3084 & 5327 & 2001 & 6469 & 7449 & 5718 & 504 & 516 & 912 & 1946 & 637 & 2225 \\
\hline $\mathrm{Nb}$ & 37.9 & 65.4 & 25.2 & 110 & 135 & 94.1 & 26.7 & 24.7 & 22 & 43.5 & 20.6 & 62.7 \\
\hline Cs & 0.89 & 1.47 & 0.66 & 1.88 & 1.98 & 1.74 & - & - & - & - & - & - \\
\hline $\mathrm{Ba}$ & 4.05 & 4.83 & 1.69 & 1.56 & 2.47 & 1.41 & 1.47 & 1.21 & 1.06 & 1.78 & 1.39 & 1.55 \\
\hline $\mathrm{Hf}$ & 9074 & 11,403 & 7523 & 11,856 & 13,484 & 10,437 & 7191 & 7547 & 6471 & 8281 & 7136 & 8593 \\
\hline Th & 618 & 1974 & 275 & 1973 & 2378 & 1497 & 62.1 & 70.2 & 64.1 & 583 & 68.5 & 658 \\
\hline $\mathrm{U}$ & 1673 & 2428 & 859 & 8437 & 8783 & 6768 & 227 & 280 & 190 & 2534 & 230 & 3582 \\
\hline $\mathrm{La}$ & 1.59 & 3.46 & 0.27 & 0.50 & 0.86 & 0.13 & 0.03 & 0.05 & 0.09 & 2.59 & 0.1 & 1.15 \\
\hline $\mathrm{Ce}$ & 26.3 & 48.9 & 16.9 & 26.9 & 30.4 & 23.1 & 7.61 & 7.04 & 4.84 & 21.3 & 5.38 & 17.8 \\
\hline $\operatorname{Pr}$ & 1.31 & 3.21 & 0.43 & 0.47 & 0.80 & 0.14 & 0.06 & 0.03 & 0.1 & 1.38 & 0.08 & 0.6 \\
\hline $\mathrm{Nd}$ & 8.69 & 23.8 & 3.72 & 4.14 & 6.05 & 2.71 & 0.86 & 0.79 & 1.54 & 8.04 & 1.15 & 4.06 \\
\hline $\mathrm{Sm}$ & 12.5 & 27.2 & 6.95 & 11.5 & 14.1 & 8.85 & 1.66 & 1.67 & 3.51 & 6.58 & 2.03 & 5.17 \\
\hline $\mathrm{Eu}$ & 0.25 & 0.46 & 0.17 & 0.13 & 0.16 & 0.04 & 0.02 & 0.03 & 0.13 & 0.01 & 0.02 & 0.02 \\
\hline $\mathrm{Gd}$ & 59.6 & 81.7 & 39.7 & 76.7 & 95.5 & 50.9 & 8.54 & 8.39 & 19.4 & 27.2 & 10.9 & 27.3 \\
\hline Dy & 257 & 284 & 200 & 461 & 552 & 335 & 36.5 & 36.7 & 70.4 & 136 & 46.8 & 159 \\
\hline $\mathrm{Er}$ & 510 & 635 & 328 & 1118 & 1299 & 897 & 75.5 & 82.2 & 140 & 302 & 98.1 & 371 \\
\hline $\mathrm{Yb}$ & 945 & 1140 & 523 & 2274 & 2384 & 1884 & 138 & 150 & 234 & 570 & 173 & 769 \\
\hline $\mathrm{Lu}$ & 140 & 168 & 77.3 & 337 & 351 & 293 & 21 & 22.9 & 36.7 & 85.3 & 27.5 & 113 \\
\hline $\mathrm{H}_{2} \mathrm{O}$ & 943 & 1500 & 723 & 1270 & 1568 & 1110 & - & - & - & - & - & - \\
\hline $\mathrm{F}$ & 22.0 & 32.3 & 13.0 & 11.4 & 15.0 & 9.76 & - & - & - & - & - & - \\
\hline Th/U & 0.38 & 0.47 & 0.31 & 0.25 & 0.28 & 0.19 & 0.27 & 0.25 & 0.34 & 0.23 & 0.3 & 0.18 \\
\hline $\mathrm{Eu} / \mathrm{Eu}^{*}$ & 0.03 & 0.04 & 0.02 & 0.01 & 0.02 & 0.01 & 0.02 & 0.03 & 0.05 & 0.00 & 0.01 & 0.01 \\
\hline $\mathrm{Ce} / \mathrm{Ce}^{*}$ & 4.91 & 11.1 & 3.98 & 11.5 & 37.3 & 9.86 & 41.4 & 42.5 & 12.8 & 2.37 & 14.2 & 5.2 \\
\hline$\Sigma$ LREE & 37.3 & 81.0 & 19.9 & 30.9 & 36.6 & 28.8 & 9 & 8 & 7 & 33 & 7 & 24 \\
\hline$\Sigma$ HREE & 1886 & 2271 & 1243 & 4280 & 4573 & 3401 & 280 & 301 & 500 & 1120 & 357 & 1440 \\
\hline
\end{tabular}




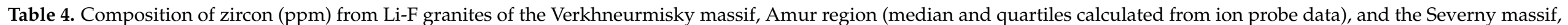
Chukotka [2], Mole massif (Australia) [41] and Zinnwald Massif (Germany) [40].

\begin{tabular}{|c|c|c|c|c|c|c|c|c|c|c|c|c|}
\hline \multicolumn{13}{|c|}{ Zircon from Li-F Granites } \\
\hline \multirow{3}{*}{ Element } & \multicolumn{6}{|c|}{ Verkhneurmisky Massif } & & & & \multirow{3}{*}{$\begin{array}{c}\text { Mole } \\
\text { Massif }\end{array}$} & \multirow{3}{*}{$\begin{array}{l}\text { Zinnwald } \\
\text { Deposit }\end{array}$} & \multirow{3}{*}{$\begin{array}{c}\text { Erzgebirge } \\
\text { Mean Value }\end{array}$} \\
\hline & \multicolumn{3}{|c|}{ Core } & \multicolumn{3}{|c|}{ Rim } & \multirow{2}{*}{\multicolumn{3}{|c|}{ Severny Massif }} & & & \\
\hline & Quartile 50\% & Quartile 75\% & Quartile 25\% & Quartile $50 \%$ & Quartile 75\% & Quartile 25\% & & & & & & \\
\hline $\mathrm{Li}$ & 0.62 & 0.82 & 0.29 & 3.38 & 9.33 & 2.41 & 5.45 & 14.1 & 0.57 & 93 & - & - \\
\hline $\mathrm{P}$ & 466 & 473 & 288 & 1137 & 1499 & 944 & - & - & - & - & 3392 & - \\
\hline $\mathrm{Ca}$ & 16.7 & 33.3 & 6.07 & 126 & 311 & 72.4 & 0.19 & 7.07 & 173 & - & 7218 & 194.9 \\
\hline $\mathrm{Ti}$ & 6.80 & 11.4 & 4.66 & 36.3 & 97.1 & 9.59 & 25.7 & 11.2 & 7.57 & - & - & 17.79 \\
\hline $\mathrm{Sr}$ & 1.31 & 1.55 & 1.05 & 6.63 & 13.2 & 3.91 & 0.57 & 1.08 & 0.56 & - & - & 1.19 \\
\hline$Y$ & 3105 & 3371 & 2168 & 6663 & 10,682 & 4240 & 659 & 572 & 1478 & 7430 & 2225 & 2864.6 \\
\hline $\mathrm{Nb}$ & 49.8 & 89.3 & 25.3 & 647 & 962 & 340 & 107 & 64.8 & 36.7 & 72.0 & - & 17.23 \\
\hline Cs & 1.98 & 11.59 & 0.50 & 9.35 & 52.59 & 4.45 & - & - & - & 14.0 & - & - \\
\hline $\mathrm{Ba}$ & 1.98 & 4.02 & 1.10 & 7.09 & 15.2 & 2.41 & 1.59 & 2.42 & 1.32 & - & - & 1.21 \\
\hline $\mathrm{Hf}$ & 7523 & 8167 & 6913 & 15,023 & 17,883 & 12,567 & 6271 & 7360 & 7260 & 15,400 & 36,400 & 8833.4 \\
\hline $\mathrm{U}$ & 1052 & 1722 & 909 & 8395 & 13,374 & 6901 & 56 & 156 & 1503 & 8192 & 6972 & 1413.2 \\
\hline $\mathrm{La}$ & 0.99 & 1.92 & 0.34 & 8.28 & 12.0 & 2.70 & 0.11 & 0.41 & 3.12 & 22.7 & - & 1.87 \\
\hline $\mathrm{Ce}$ & 15.5 & 17.6 & 11.0 & 64.4 & 92.5 & 44.0 & 33.6 & 28.6 & 27.5 & 111 & - & 18.15 \\
\hline $\operatorname{Pr}$ & 0.77 & 1.74 & 0.28 & 4.85 & 7.72 & 1.80 & 0.21 & 0.64 & 1.84 & 13.0 & 85 & 1.15 \\
\hline $\mathrm{Nd}$ & 7.04 & 13.10 & 3.32 & 29.36 & 42.71 & 12.11 & 2.08 & 4.78 & 9.29 & 70.0 & - & 10.63 \\
\hline Sm & 15.53 & 19.51 & 8.07 & 30.05 & 50.15 & 20.29 & 3.73 & 4.48 & 7.21 & 48.9 & 345 & 14.27 \\
\hline $\mathrm{Eu}$ & 0.16 & 0.36 & 0.14 & 0.29 & 0.49 & 0.12 & 0.32 & 0.5 & 0.01 & 1.30 & - & 1.29 \\
\hline
\end{tabular}


Table 4. Cont.

\begin{tabular}{|c|c|c|c|c|c|c|c|c|c|c|c|c|}
\hline \multicolumn{13}{|c|}{ Zircon from Li-F Granites } \\
\hline \multirow{3}{*}{ Element } & \multicolumn{6}{|c|}{ Verkhneurmisky Massif } & & & & \multirow{3}{*}{$\begin{array}{c}\text { Mole } \\
\text { Massif }\end{array}$} & \multirow{3}{*}{$\begin{array}{c}\text { Zinnwald } \\
\text { Deposit }\end{array}$} & \multirow{3}{*}{$\begin{array}{c}\text { Erzgebirge } \\
\text { Mean Valu }\end{array}$} \\
\hline & \multicolumn{3}{|c|}{ Core } & \multicolumn{3}{|c|}{$\operatorname{Rim}$} & \multirow{2}{*}{\multicolumn{3}{|c|}{ Severny Massif }} & & & \\
\hline & Quartile 50\% & Quartile $75 \%$ & Quartile 25\% & Quartile 50\% & Quartile 75\% & Quartile 25\% & & & & & & \\
\hline $\mathrm{Gd}$ & 54.7 & 69.9 & 45.3 & 102 & 145 & 65.2 & 15.0 & 11.9 & 25.8 & 143 & - & 63.44 \\
\hline Dy & 218 & 312 & 163 & 541 & 824 & 382 & 49.7 & 39.1 & 110 & 713 & 1505 & 255.1 \\
\hline Er & 456 & 566 & 320 & 1361 & 2011 & 1001 & 92.7 & 84.2 & 224 & 1227 & 2838 & 467.2 \\
\hline $\mathrm{Yb}$ & 835 & 947 & 622 & 3661 & 4678 & 2495 & 168 & 194 & 398 & 2742 & 10,315 & 745.1 \\
\hline $\mathrm{Lu}$ & 124 & 146 & 115 & 515 & 668 & 379 & 25.2 & 30.9 & 59.2 & 475 & - & 112.5 \\
\hline $\mathrm{H}_{2} \mathrm{O}$ & 536 & 853 & 418 & 2294 & 3974 & 1323 & - & - & - & - & - & - \\
\hline $\mathrm{F}$ & 66.4 & 87.3 & 20.5 & 186 & 345 & 108 & - & - & - & - & 8400 & - \\
\hline Th/U & 0.40 & 0.51 & 0.37 & 0.22 & 0.30 & 0.16 & 0.54 & 0.32 & 0.25 & 0.31 & 0.33 & 0.21 \\
\hline $\mathrm{Eu} / \mathrm{Eu}^{*}$ & 0.02 & 0.04 & 0.02 & 0.02 & 0.02 & 0.01 & 0.13 & 0.21 & 0.01 & 0.05 & - & 0.13 \\
\hline $\mathrm{Ce} / \mathrm{Ce}^{*}$ & 5.63 & 9.13 & 3.68 & 2.32 & 5.26 & 1.79 & 53.7 & 13.4 & 2.78 & 1.60 & - & 2.99 \\
\hline इHREE & 1707 & 2058 & 1250 & 6485 & 8740 & 4390 & 350 & 360 & 817 & 5907 & 14,658 & 1643.38 \\
\hline
\end{tabular}


Analyzing the published data, we can say that, in general, the level of trace elements content in zircon from granitoids is relatively low: Hf $(0.39-3.98 \%), \mathrm{Y}(0.1-0.5 \%), \mathrm{REE}, \mathrm{P}$, $\mathrm{U}$, Th (up to $0.5 \%$ ), and $\sim 0.0 \mathrm{n} \%$ for the rest [42]. An exception is a zircon from the Li-F granites from Europe (Bohemia; Carpathians), Australia (New England batholith), Asia (Transbaikalia), Africa (Arabian desert), and North America (Guadalupe Mountains), with concentrations of rare elements reaching $10 \mathrm{wt} . \%$ or more [2,43].

The studied zircon from the Verkhneurmiysky granites (both biotite leucogranites and zinnwaldite granites) demonstrates the most similar composition with zircon from Chukotka granites (Severny massif), as well as with zircon from rare-metal topaz-bearing granites of the Mole massif (Australia) [41], Zinnwald Massif (Germany) [40], and Erzgebirge (Germany) [44] where REE concentrations almost reach the level of hydrothermal mineralization $[41,45]$.

The distinctive feature of zircon from Verkhneurmiysky granites is the increased content of Hf, reaching the level of zircon from the granite of the Erzgebirge (Germany) and Mole massif (Australia). Hf content is significantly increased in the altered rims of the studied zircon, reflecting the process of the melt differentiation and hydrothermal alterations, and almost reach the anomalous values typical of zircon from Zinnwald granite (Figure 14a). Compared to zircon of the Severny Massif, the Verkhneurmiysky zircon shows approximately equal levels of actinoids (Th, U) and high-field-strength (HFS) elements (Ti, $\mathrm{Nb}$ ) and sharply increased levels of both groups of elements in the altered zircon rims in Zrn-Znw (Figure 14b).

(a)

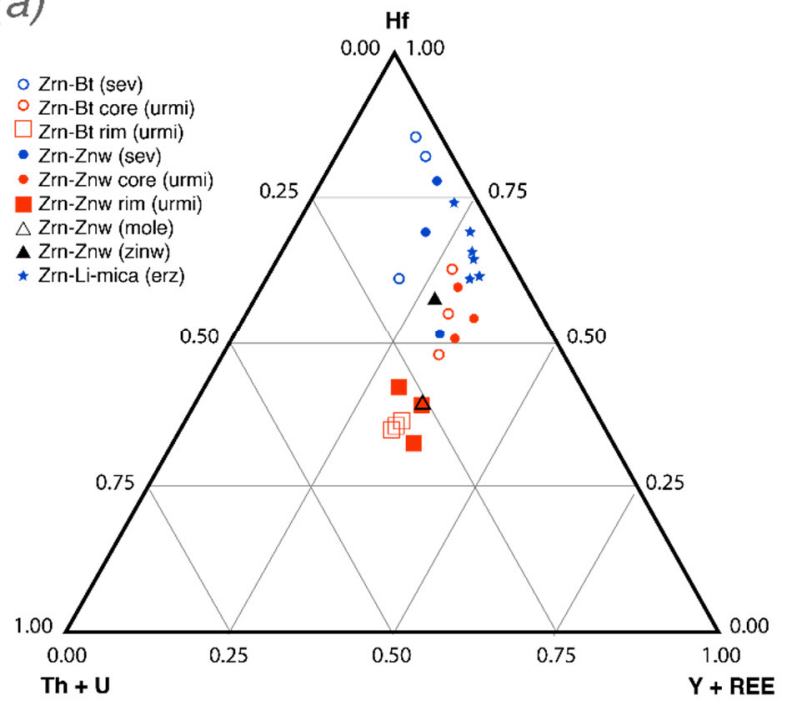

(b)

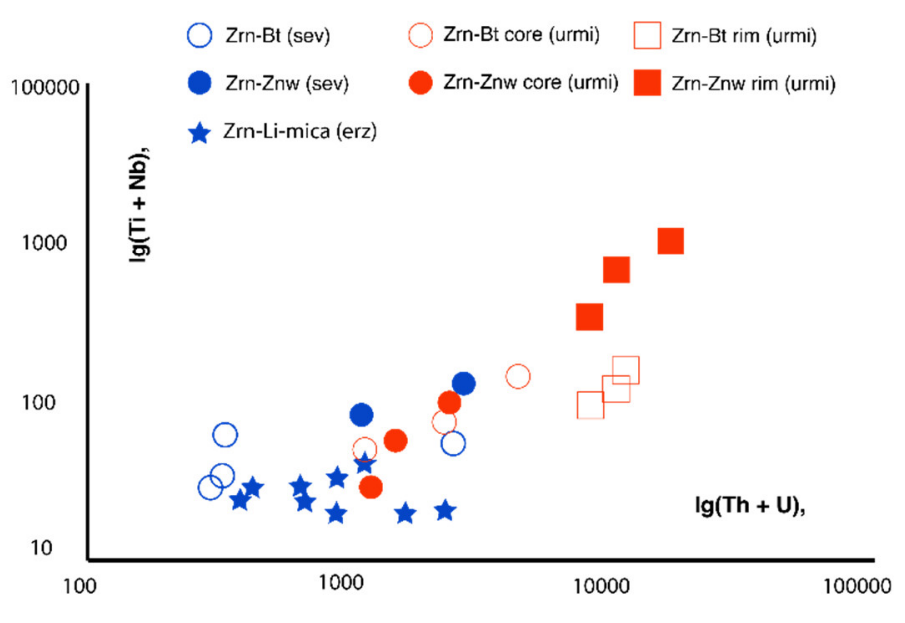

Figure 14. Discrimination charts of zircon composition from biotite (Bt) and zinnwaldite (Znw) granites of Verkhneurmisky (Urmi), Severny (Sev), Mole (Sev), Zinwald (Zinw), and Erzgebirge (Erz) massifs in (a) (Th + U) - Hf-(Y + REE) and $(\mathbf{b})(\mathrm{Th}+\mathrm{U})-(\mathrm{Ti}+\mathrm{Nb})$ coordinates.

The electron-microscopic studies have already shown that all zircon types from Verkhneurmiysky granites show anomalously high concentrations of $U$, Th, REE, and Y. According to many researchers [46-48], the probability of finding these elements in the structure of zircon as an isomorphic impurity is small; whereas they rather form their own minerals enclosed in the zircon matrix. From this point of view, anomalous U, Th, REE, and $Y$ concentrations associated with their own minerals (uraninite, coffinite, thorite, monazite, allanite, etc.), either captured during crystal growth or formed in the process of zircon secondary alterations, are quite understandable. Such anomalous values were not considered in the composition analysis of zircon under study.

The ion microprobe analysis of zircon also allows limiting the samples by the grain alteration degree and titanium content for the correct application of the Ti-in-zircon ther- 
mometer [49-51]. Thus, the median values of Ti-in-zircon temperatures, calculated for the unaltered zircons with a Ti content not exceeding $30 \mathrm{ppm}$, are $831{ }^{\circ} \mathrm{C}$ and $710^{\circ} \mathrm{C}$ for the Zrn-Bt and Zrn-Znw, respectively. Zircon saturation thermometry [52-54], based on the granite's composition (Table 1$)$ and calculated with $\mathrm{M}=(\mathrm{Na}+\mathrm{K}+2 \cdot \mathrm{Ca}) /(\mathrm{Al} \cdot \mathrm{Si})$, provides the values of $761{ }^{\circ} \mathrm{C}$ and $685{ }^{\circ} \mathrm{C}$ for the Zrn-Bt and Zrn-Znw, respectively. Despite the discrepancy between the absolute temperature values, obtained by different methods, the fact that the temperature of zircon formation decreases with time seems to be reliable.

Even in the case of pronounced contrast of morphology, microtexture, and zoning of zircon, the convergence of these features complicates the ambiguity of zircon typing. The relative reliability of Zrn-Znw type definition is achieved only when we consider the element composition. According to the results of the study on the zircon internal structure, the dataset of zircons in situ analysis was divided into the "core" and "rim" groups. The need for such separation was confirmed on the factor score diagrams for each sample, where the points corresponding to cores and rims are clearly split up (Figure 15).

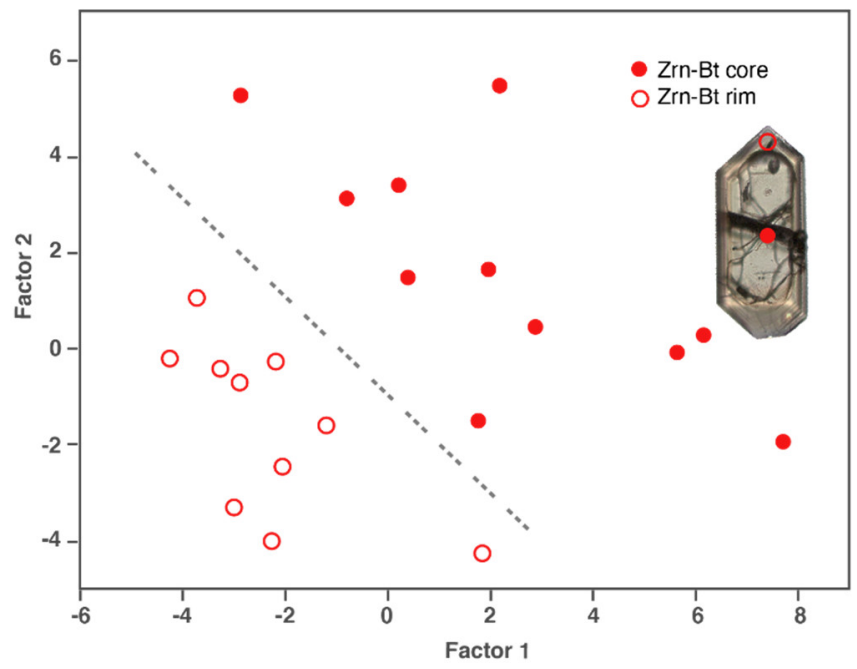

(a)

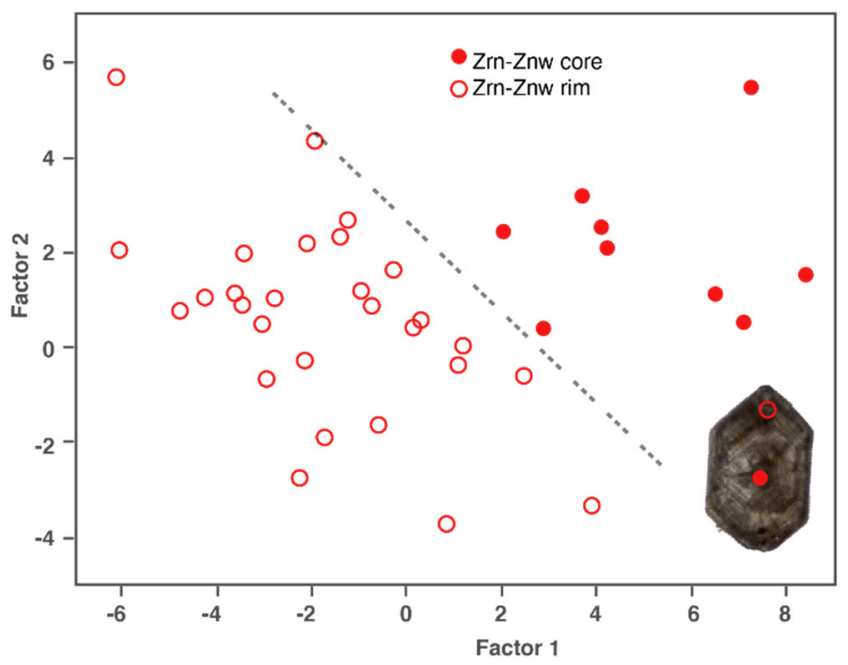

(b)

Figure 15. Factor score diagrams showing two fields of analytical points corresponding to the cores and altered rims of zircon from: biotite (a) and zinnwaldite (b) granites.

Thus, it is reasonable to consider the relationships between cores and rims within each zircon type, assuming that the magmatic history of zircon formation should be reflected in compositional and structural changes of the unaltered central domains of grains, while the intensity of the secondary alterations affects the composition of rims. The accumulation of $\mathrm{U}, \mathrm{Th}, \mathrm{Nb}, \mathrm{HREE}, \mathrm{Cs}, \mathrm{P}, \mathrm{Y}, \mathrm{Li}, \mathrm{Sr}, \mathrm{H}_{2} \mathrm{O}$, and $\mathrm{Hf}$ (in descending order of accumulation intensity) and decrease in LREE, F, Ba, Ca, and Ti concentrations (Figure 16a,c) are observed in the rims of zircon from biotite granite. Zircon from zinnwaldite granite demonstrates a general increase in the concentrations of all trace elements (Figure 16a,c).

It is interesting to note that there are no significant variations in the composition of the central unaltered domains in zircon from different granites, which suggests similar physical and chemical parameters of zircon crystallization during the formation of the Verkhneurmiysky granitoid series (Figure 16a). Zircon from zinnwaldite granites has only initially slightly increased content of $\mathrm{F}, \mathrm{Cs}$, and $\mathrm{Nb}$, emphasized by increasing zircon/melt distribution coefficients in the transition from biotite to zinnwaldite granites, which is likely a reflection of the increased degree of emanation differentiation in the final stages of granite magmatism. Additionally, cores are characterized by the REE spectra typical for magmatic zircon - the smooth growth of chondrite-normalized REE concentrations with an increase in atomic number, disturbed by Ce- and Eu-anomalies. Zircon from zinnwaldite granite differs in a slightly lower content of LREE and a bit weaker Ce-anomaly 
(Figure 16c,d). Positive Ce-anomaly is controlled by oxygen fugacity and is explained by the fact that $\mathrm{Ce}^{4+}$ is incorporated in the structure of zircon according to the isovalent isomorphism. Moreover, the radius of $\mathrm{Ce}^{4+}$ ion is close to HREE ones, so the calculated value of zircon/melt distribution coefficient for $\mathrm{Ce}^{4+}$ is several orders of magnitude higher than for $\mathrm{Ce}^{3+}$. The depth of the Eu-anomaly depends on the $\mathrm{Eu}^{2+} / \mathrm{Eu}^{3+}$ ratio, and its manifestation in zircon REE spectra is caused by early processes of acid melts appearance as a result of crystallization differentiation. However, in this case, it seems more likely to associate the variations of Eu-anomaly in the melt not only with the participation of feldspars in the crystallization process but also with the fluid differentiation.

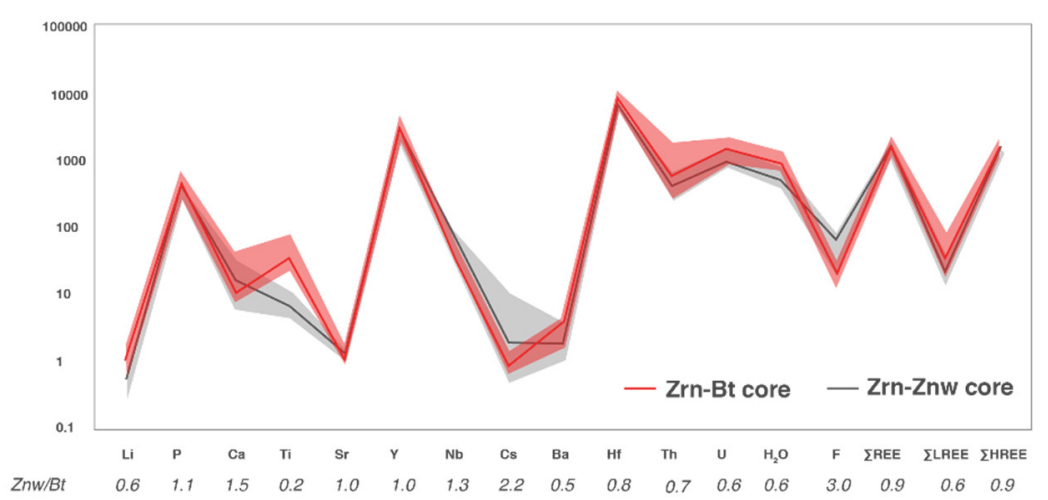

(a)

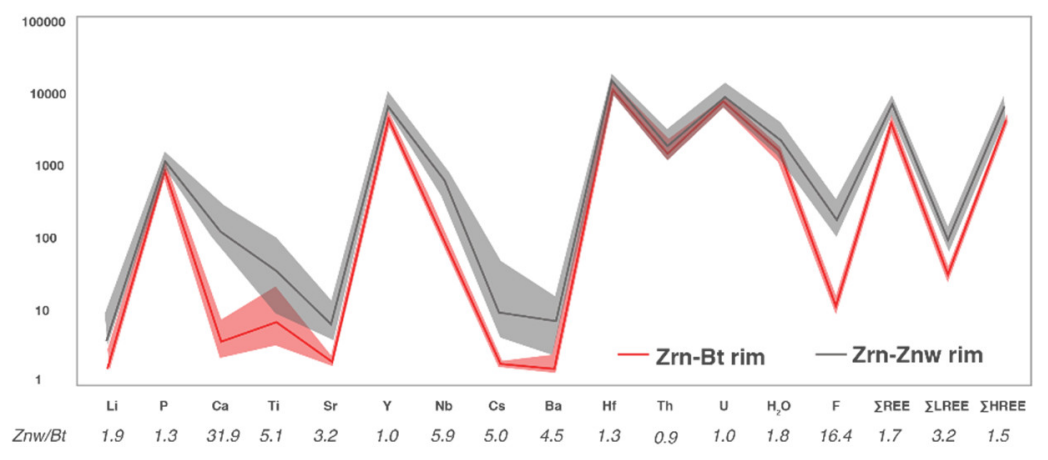

(c)

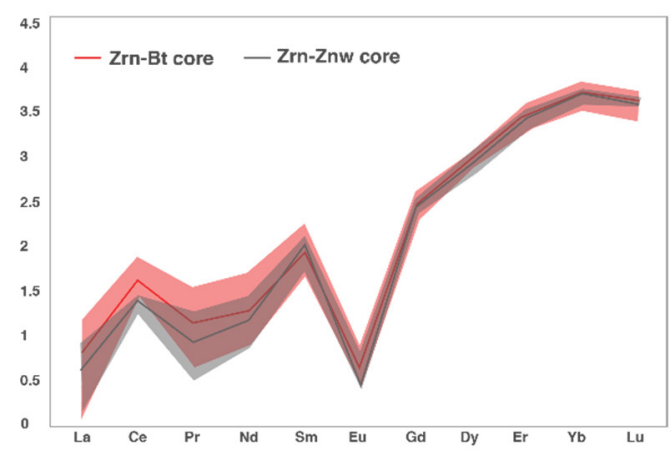

(b)

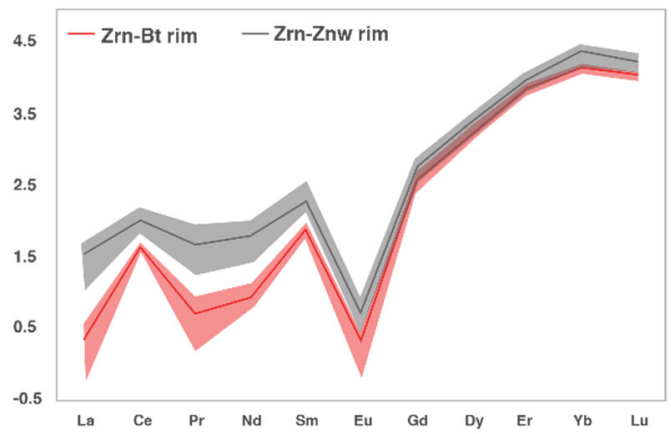

(d)

Figure 16. Contents of trace elements and REE spectra in $(\mathbf{a}, \mathbf{b})$ cores and (c,d) rims of zircon grains from biotite Zrn-Bt and zinnwaldite Zrn-Znw granites; solid lines—median values, dashed lines—upper/lower quartile boundaries.

Against the similar composition of cores in zircon of different types, the content of trace elements in the altered crystals domains experiences a sharp jump in the transition from Zrn-Bt to Zrn-Znw, which can be caused by the active influence of fluid phase accompanying the intrusion of the zinnwaldite granites. This assumption is also supported by the widespread secondary alterations in zircon Zrn-Znw, such as a decrease in the degree of grains crystallinity and the development of spongy texture, saturated with pores and inclusions. It should be noted that the set of elements (, ,, Th, and $U)$ corresponding to the composition of common mineral inclusions (xenotime, coffinite, and thorite) has an approximately equal level of concentrations in the rims of all zircons under study. This suggests that the evolution of zircon composition is regulated not only and not so much by the parameters of the crystallization medium as by the isomorphic capacity of the mineral lattice. REE spectra illustrate sharp enrichment of altered Zrn-Znw domains with rare earth elements, with the flattering on the left side of the spectrum (LREE), reduction of Ce-anomaly, and decrease in the $\Sigma$ HREE/ $\Sigma$ LREE ratio. This may be the result of a destructive fluid effect on the zircon lattice that facilitates the isomorphism of LREE [55] (Figure 16d). 
The $\mathrm{SmN} / \mathrm{LaN}$ ratio together with the Ce-anomaly $\left(\mathrm{Ce} / \mathrm{Ce}^{*}\right)$ value allows tracing the distribution of points corresponding to zircon from biotite leucogranites and zinnwaldite granites between the fields of magmatic and hydrothermal zircon [56]. The density of Zrn-Znw sampling points distribution shows maximum near the field of hydrothermal zircon. Consequently, a relative enrichment of $\mathrm{Ce}^{3+}$ is observed for Zrn-Znw, which is typical for secondary altered zircons [57]. The separation of Zrn-Bt and Zrn-Znw on the diagram in $\mathrm{SmN} / \mathrm{LaN}-\mathrm{Ce} / \mathrm{Ce}^{*}$ coordinates illustrates the full post-magmatic processing of magmatic zircon from zinnwaldite granites and serves as its additional characteristic.

Statistical analysis of zircon composition data included the results of preliminary correlation analysis of SIMS data, which revealed a strong correlation between such groups of elements as $\mathrm{Cs}, \mathrm{Sr}$, and $\mathrm{P} ; \mathrm{Ca}, \mathrm{Ba}$, and $\mathrm{Li}$ in zircon from biotite granites, and the absence of such correlations, along with the shift of the negative correlation between $\mathrm{Ca}$ and $\mathrm{Sr}$, on the strong positive one in zircon from zinnwaldite granites. $\mathrm{Zrn}-\mathrm{Znw}$ is characterized by a strong positive correlation between halogens (F), LIL (Ba, Cs), LREE, and $\mathrm{H}_{2} \mathrm{O}$, which is explained by the formation of late magmatic $\mathrm{Zrn}-\mathrm{Znw}$ grains with active gas evaporation from the fluid-saturated melt and imperfection of Zrn-Znw structure caused by fluid action and facilitating the entrance of incompatible elements into the zircon structure. Similar dependencies in zircon Zrn-Bt are very weak and are due to the contribution of rare-metal rims, which formed around the early magmatic zircon during the intrusion of the Li-F granites. The principal component analysis allowed interpreting two significant factors overlapping $73 \%$ of the total dispersion (Figure 17a): the first factor is the formation of rims enriched with impurities under the temperature decrease; the second factor reflects the process of REE fractionation, and the formation of mineral inclusions (xenotime, thorite, coffinite) in the altered zircon domains. The reliability of interpretation of the first factor is confirmed by the factor score diagrams, where the points corresponding to cores and rims are clearly split up (Figure 17b).

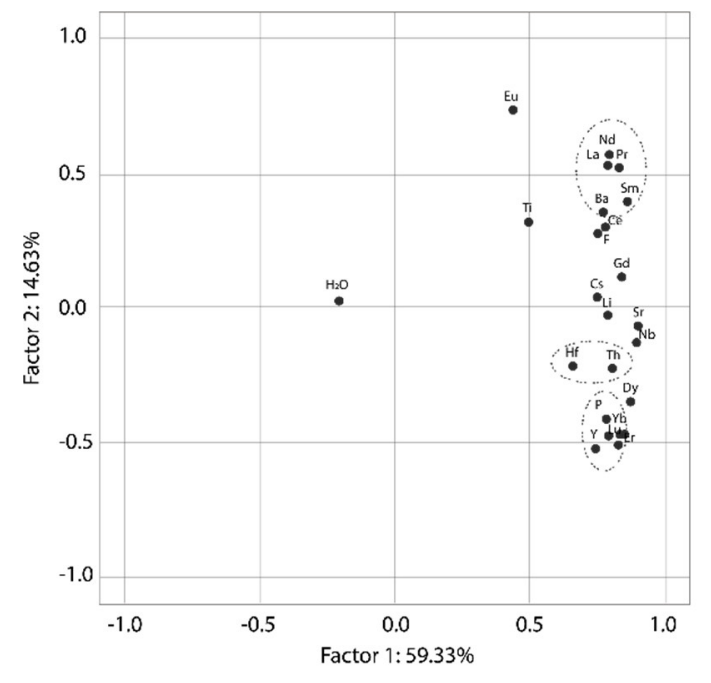

(a)

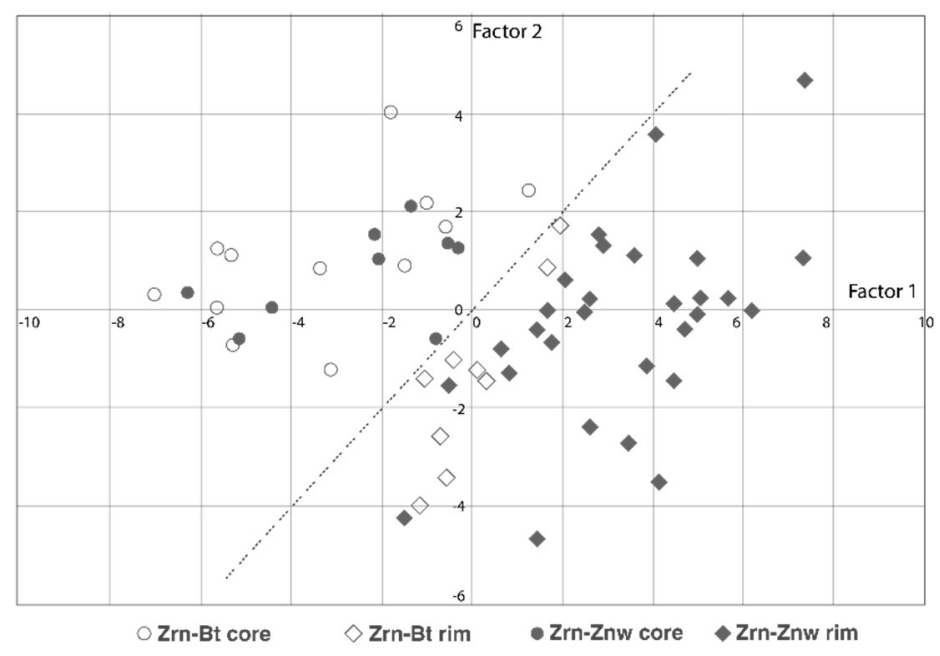

(b)

Figure 17. (a) Factor loadings and (b) factor scores graphs plotted for the general sample of zircon from the Verkhneurmiysky granitoids.

Thus, we identified the main trends in the composition evolution of zircon from the Verkhneurmiysky intrusive series with Li-F granites, which are determined by both the degree of melt differentiation and the intensity of post-magmatic processes, as well as the special features of the zircon lattice: accumulation of HFS $(\mathrm{Hf}, \mathrm{Nb})$ and rare-earth (REE, Y) elements at a decrease in the Th/U ratio, which sensitively records the degree of zircon recrystallization and positively correlates with Eu-anomaly (Figure 18a); an abrupt increase in the concentration of volatile $\left(\mathrm{H}_{2} \mathrm{O}, \mathrm{F}\right)$ and rare alkalis $(\mathrm{Li}, \mathrm{Cs})$ at the formation 
of Li-F granites, which directly affected the alteration of zircon from biotite leucogranites (Figure 18b).

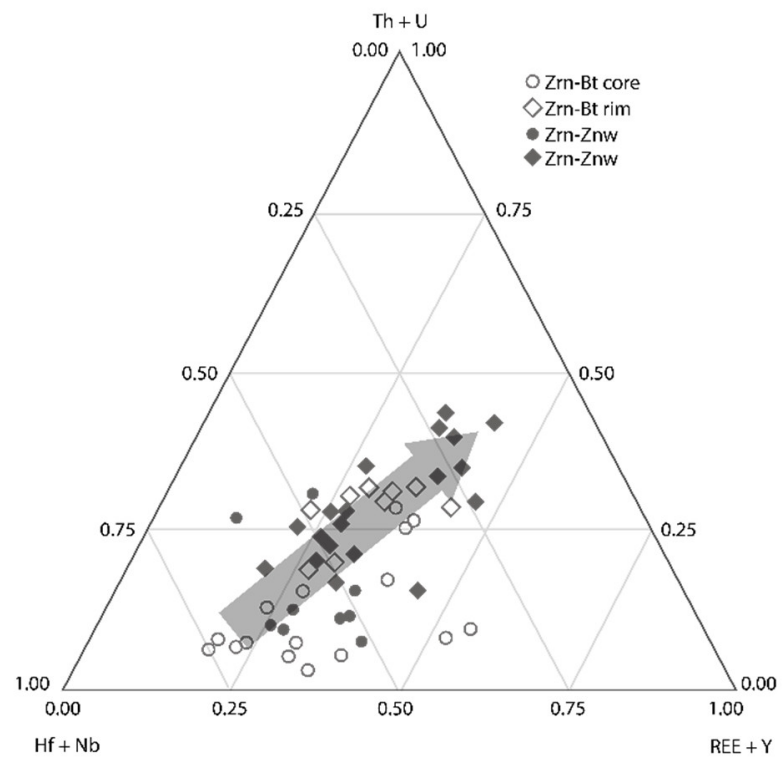

(a)

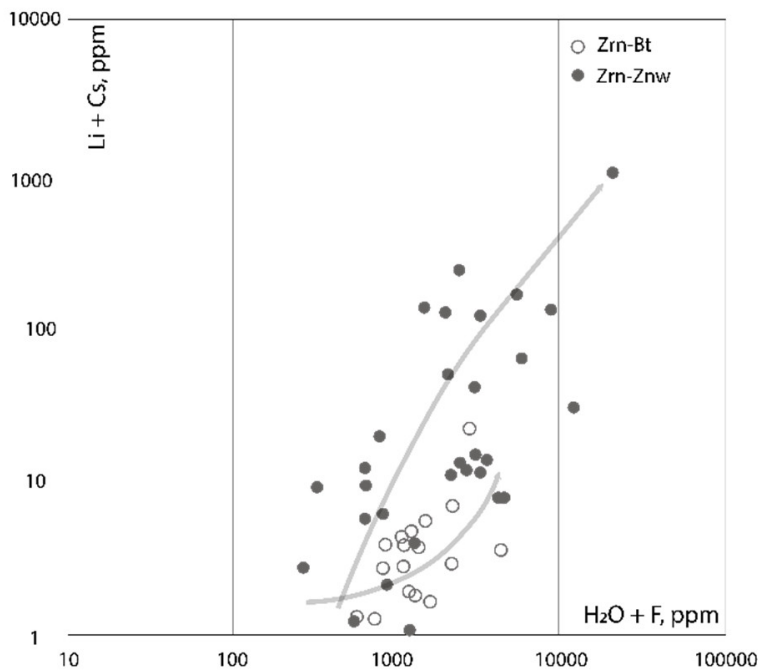

(b)

Figure 18. (a) Trend of accumulation of HFS and rare-earth elements with an increase in the gradient of uranium concentration; (b) abrupt increase in the concentration of volatile and rare alkalis at the stage of Li-F granites formation, which had a direct impact on the alteration of zircon from biotite leucogranites.

\subsection{Raman Spectroscopy of Zircon}

The set of rather conformal spectra and wavenumbers of Raman modes for both zircon types under study agree with other studies $[24,25,58,59]$ and characterized by the left side wave-shaped curves elevation with the extremum value in the range of $200-350 \mathrm{~cm}^{-1}$, overlapping an external translational $\left(202,225,355 \mathrm{~cm}^{-1}\right)$ modes of $\mathrm{SiO}_{4}$ tetrahedra (Figure 19).
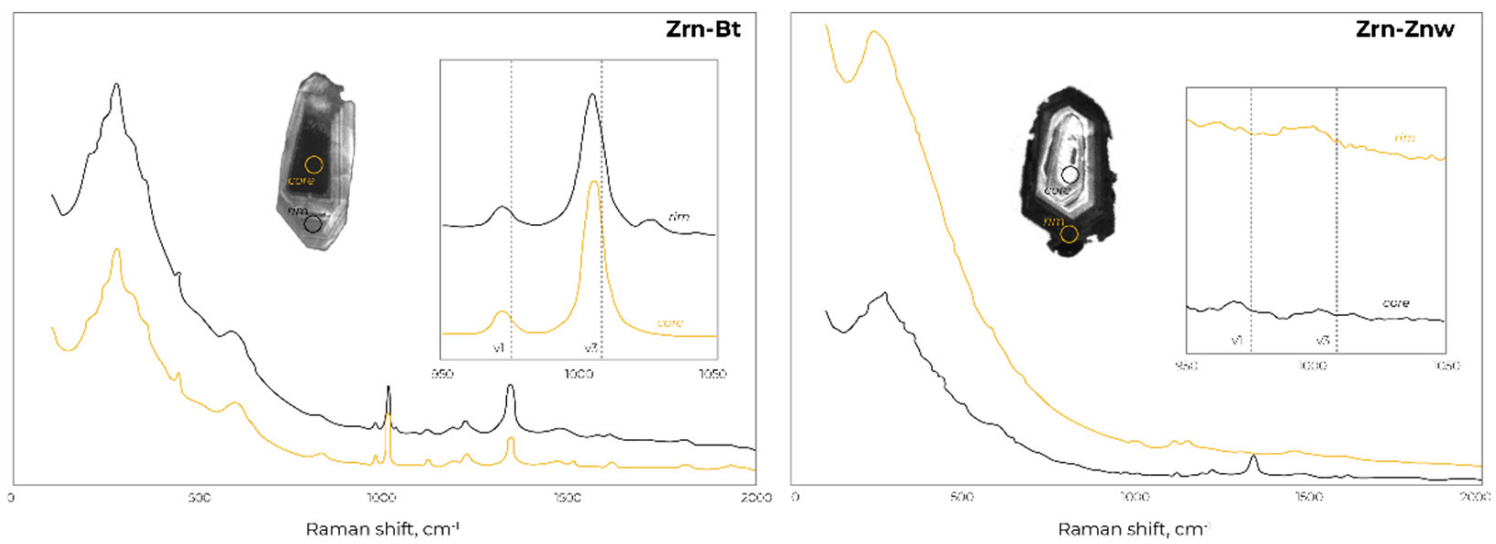

Figure 19. Raman spectra of zircon from biotite (Zrn-Bt) and zinnwaldite (Zrn-Znw) granites at the certain points corresponding to the zircon ion microprobe analytical points; the dotted red lines indicate the position of the characteristic peaks of $\mathrm{SiO}_{4}$ oscillations in crystalline zircon: $v_{1}-975 \mathrm{~cm}^{-1}, v_{3}-1008 \mathrm{~cm}^{-1}$.

The spectra of the Zrn-Znw without distinction of core/rim crystal zones are characterized by whole peaks reduction grading into the wave-shaped curves. Whereas in passing from core to rim in the vast majority of Zrn-Bt grains, there is a gradual shift in the red 
region for the $v_{1}\left(\mathrm{SiO}_{4}\right)$ and $v_{3}\left(\mathrm{SiO}_{4}\right)$ peaks, accompanied by peak tailing up to complete disappearance of the peaks and the emergence of so-called amorphous halo, typical for zircon enriched in REE and resulting from laser-induced fluorescence emissions of the luminophor impurities [58]. In some cases, Raman spectra of the Zrn-Bt rims are similar to Zrn-Znw spectra along the whole grain, which could indicate the same alteration processes. In the light CL-zones (principally corresponding with core zones) of the Zrn-Bt crystals, FWHM of the $v_{3}\left(\mathrm{SiO}_{4}\right)$ band ranges from 8.7 to $18.4 \mathrm{~cm}^{-1}$, which suggests only a partial amorphization of the crystal structure (so-called transit state). The peak reduction in the spectra of the zircon rim gives evidence of significant structural radiation damage (FWHM minimum value is $29.1 \mathrm{~cm}^{-1}$ ), leading to an increase in the zircon reactive capacity and dramatic accumulation of trace elements [59].

The coincidence of Raman and ion microprobe analytical points make it possible to trace the relationship between the characteristics of the $v_{3}\left(\mathrm{SiO}_{4}\right)$ peak with the composition of zircon, expressing them through appropriate correlations. As consequence, it was revealed that the peak broadening and the value of the Raman shift expectedly decrease with the increase in LREE, Li, F content and Th/ $\mathrm{U}$ ratio. However, the increasing Ceanomaly value is accompanied by an increase in Raman shift magnitude of $v_{3}\left(\mathrm{SiO}_{4}\right)$ peak. Shown correlation is regular from the standpoint of $\mathrm{Ce}^{4+}$ incorporating into the zircon crystal structure according to the isovalent substitution model: due to the proximity of $\mathrm{Ce}^{4+}(0.097 \mathrm{~nm})$ and $\mathrm{Zr}^{4+}(0.084 \mathrm{~nm})$ ionic radius, isomorphic occurrence of $\mathrm{Ce}^{4+}$ in $\mathrm{Zr}^{4+}$ position does not lead to significant distortions of the zircon crystal lattice. The reduction of zircon crystallinity accompanied by the broadening and redshift of the $v_{3}\left(\mathrm{SiO}_{4}\right)$ peak is also confirmed by the decrease in the degree of REE fractionation $(\mathrm{LuN} / \mathrm{LaN})$ specific to altered zircon.

\section{Conclusions}

The result of this study is a complex characteristic of zircon from the Verkhneurmiysky intrusive series with Li-F granites. A wide range of morphological and chemical features of zircon allowed to obtain new information on the formation and alteration of zircon from granitoids of different types and to determine a set of zircon characteristic features, which contribute to the correct identification of Li-F granites formed directly before the tin mineralization within the Verkhneurmiysky massif.

The division into varieties by the coefficient of crystal elongation contributed to an adequate interpretation of the morphotype distribution and facilitated the establishment of zircon stages of evolution even within a single sample.

We also found that the change in the trace elements content level on the way from zircon cores to its rims are quite different in zircon from biotite ( $\mathrm{Zrn}-\mathrm{Bt}$ ) and zinwalditic (Zrn-Znw) granites with the maximum impurities' accumulation level in the rims of zircon from zinwalditic ones. Active fluid evaporation and their transporting role is the reason for the secondary alterations affected not only zircon from the rare-metal granites but also from the early biotite granites, which led to the accumulation of a wide range of trace elements ( $\mathrm{Ca}, \mathrm{Ti}, \mathrm{Ba}, \mathrm{F}, \mathrm{Cs}, \mathrm{Eu}, \mathrm{La}, \mathrm{Li}, \mathrm{Pr}, \mathrm{P}, \mathrm{Nb}, \mathrm{Lu}, \mathrm{Yb}, \mathrm{Nd}$, and $\mathrm{Hf}$ ) in the altered zircon rims. The main trend in the evolution of zircon composition is the progressive accumulation of volatile $\left(\mathrm{H}_{2} \mathrm{O}, \mathrm{F}\right)$, LIL (Cs, Sr), HFS (Hf, $\left.\mathrm{Nb}\right)$, and rare-earth elements. The evolution of zircon morphology is not only the fact, that the low-temperature zircon morphotypes expectedly followed the high-temperature ones, but also the complication of the zircon structure in time- the formation of rare metal rims, the spread of secondary alteration zones with the crystal lattice disturbance, mineral inclusions, pores, and cracks. The Raman spectra of Zrn-Bt and Zrn-Znw show zircon crystallinity reduction through the formation of Verkhneurmiysky granitoid series. The reduction of zircon crystallinity is also verified by an increase in uranium accumulation gradient and resulting in an extension of the isomorphic capacity of zircon lattice with naturally determined accumulation of rare-earth (REE, Y) elements and abrupt increase in the concentration of volatiles (F) and rare alkalis (Li) at the stage of lithium-fluorine granites formation. 
The composition and morphology of the studied zircon from zinnwaldite granites are similar to zircon from the Li-F granite of Severny Massif (Chukotka), the Mole Massif (Australia), the Erzgebirge (Germany, Czech Republic), which allows the possibility of using the identified complex of zircon features for the correct revealing of the Li-F granites.

Author Contributions: M.M.M.—-methodology, investigation, writing—original draft preparation, supervision, visualization; A.V.A.—resources, data curation, conceptualization, software; J.B.writing - review and editing, validation, formal analysis, project administration. All authors have read and agreed to the published version of the manuscript.

Funding: This research received no external funding.

Institutional Review Board Statement: Not applicable.

Informed Consent Statement: Not applicable.

Data Availability Statement: The data presented in this study are available in this article.

Acknowledgments: The studies were performed using the equipment of the Common Use Centre of the Saint Petersburg Mining University; we thank Yu. B. Marin, V.I. Alekseev, and S.G. Skublov. We express gratitude to the academic editor and three anonymous reviewers for critically reading the manuscript and suggesting substantial improvements.

Conflicts of Interest: The authors declare no conflict of interest. The funders had no role in the design of the study; in the collection, analyses, or interpretation of data; in the writing of the manuscript, or in the decision to publish the results.

\section{References}

1. Maiboroda, A.F.; Emelianenko, A.S.; Vtorushina, V.F. Scheme of magmatism of the Badzhal volcanic zone. Rep. USSR Acad. Sci. 1977, 235, 155-158.

2. Alekseev, V.I. Li-F Granites of the Far East. Ph.D. Thesis, Geological and Mineralogical Sciences, Mining University, Saint Petersburg, Russia, 2014.

3. Vdovina, I.A. Evaluation of the Denudation Sheet of the Badzhal Ore Region by Morphostructural and Crystal Morphological Methods; Candidate of Geography, Institute of Geography: Moscow, Russia, 2004.

4. Stepanov, V.A.; Melnikov, A.V. Deposits of gold-quartz formation of the Amur province. J. Min. Inst. 2017, 223, 20.

5. Brusnitsin, A.I.; Panova, E.G.; Smolensky, V.V. The discovery of Li-F granites within the Verkhneurmiysky ore cluster. Izv. VUZov. Geol. Explor. 1993, 6, 150-151.

6. Krivovichev, V.G.; Brusnitsin, A.I.; Zaitsev, A.N. Absolute age and geochemical characteristics of granites of the Verkhneurmiysky massif (Priamurye, Far East). Geochemistry 1996, 2, 106-111.

7. Rodionov, S.M. Tin Metallogeny of the Russian East. Ph.D. Thesis, Geological and Mineralogical Sciences, Lomonosov Moscow State University, Moscow, Russia, 2003.

8. Grigoriev, S.I. Features of the material composition of the Late Mesozoic granitoids of the Badzhal and Komsomolsk ore regions, their petrogenesis and connection with mineralization. Reg. Geol. Metallog. 1997, 6, 103-115.

9. Gonevchuk, V.G. Tin-Bearing Magmatic Systems of the Far East: Magmatism and Ore Genesis; Dalnauka: Vladivostok, Russia, 2002; pp. 140-167.

10. Alekseev, V.I. Rare metals in minerals of tin-bearing metasomatites of the Verkhneurmiysky ore cluster (Far East of Russia). J. Min. Inst. 2018, 232, 335-340.

11. Dobretsov, G.L.; Marin, Y.B.; Beskin, S.M.; Leskov, S.A. Principles of Dissection and Mapping of Granitoid Intrusions and Identification of Petrological-Metallogenic Variants of Granitoid Series; VSEGEI Publishing House: Saint Petersburg, Russia, 2007 ; pp. $39-56$.

12. Marin, Y.B.; Beskin, S.M. Typification of rare-metal granites and forecast of rare-metal mineralization. In Proceedings of the International Petrographic Meeting "Petrography of the XXI Century", Petrology and Ore Content of the CIS Regions and the Baltic Shield, Apatity, Russia, 28-30 June 2005; pp. 47-48.

13. Beskin, S.M.; Marin, Y.B.; Matthias, V.V. So what exactly is "rare metal granite"? Zapiski RMS 1999, 6, $28-40$.

14. Alekseev, V.I.; Sukhanova, K.G.; Marin, Y.B. Niobium Minerals as Indicators of a Genetic Link between Tin-Bearing Zwitter and Lithium-Fluorine Granite of the Verkhneurmiysky Massif in the Amur River Region. Geol. Ore Depos. 2019, 8, 698-707. [CrossRef]

15. Skublov, S.G.; Krasotkina, A.O.; Makeev, A.B.; Rizvanova, N.G.; Koiman, E. The first data on the age (U-Pb method, TIMS, LA-ICP-MS) of rutile from the polymineral ore occurrence Ichetyu, Middle Timan. J. Min. Inst. 2018, 232, $357-363$.

16. Frost, B.R.; Barnes, C.G.; Collins, W.J.; Arculus, R.J.; Ellis, D.J.; Frost, C.D. A geochemical classification of granitic rocks. J. Petrol. 2001, 42, 2033-2048. [CrossRef]

17. Breiter, K.; Škoda, R. Vertical zonality of fractionated granite plutons reflected in zircon chemistry: The Cínovec A-type versus the Beauvoir S-type suite. Geol. Carpathica 2012, 63, 383-398. [CrossRef] 
18. Nikolaeva, N.; Aleksandrova, T.; Romashev, A. Effect of grinding on the fractional composition of polymineral laminated bituminous shales. Miner. Process. Extr. Metall. Rev. 2018, 39, 231-234. [CrossRef]

19. Pashkevich, M.A.; Petrova, T.A. Recyclability of ore beneficiation wastes at the Lomonosov Deposit. J. Ecol. Eng. 2019, 20, 27-33. [CrossRef]

20. Sirotkin, A.N.; Talovina, I.V.; Duryagina, A.M. Mineralogy and geochemistry of alkaline lamprophyres of north-western Spitsbergen (Svalbard). Chem. Erde 2020, 80, 125508. [CrossRef]

21. Fedotova, A.A.; Bibikova, E.V.; Simakin, S.G. Zircon Geochemistry (Ionic Microprobe Data) as an Indicator of Mineral Genesis in Geochronological Research. Geochemistry 2008, 9, 980-997.

22. Popov, O.A.; Talovina, I.V.; Lieberwirth, H.; Duryagina, A.M. Quantitative microstructural analysis and X-ray computed tomography of ores and rocks-Comparison of results. Minerals 2020, 2, 129. [CrossRef]

23. McDonough, W.F.; Sun, S.S. The composition of the Earth. Chem. Geol. 1995, 120, 223-253. [CrossRef]

24. Dawson, P.; Hargreave, M.M.; Wilkinson, G.R. The vibrational spectrum of zircon $\left(\mathrm{ZrSiO}_{4}\right)$. J. Phys. C 1971, 4, 240-256. [CrossRef]

25. Gusik, A.; Zhang, M.; Koeberl, C.; Salje, E.; Redfern, S.; Pruenda, M. Infrared and Raman spectra of $\mathrm{ZrSiO}_{4}$ experimentally shocked at high pressures. Mineral. Mag. 2004, 65, 801-811. [CrossRef]

26. Mikheeva, P.I.; Alekseev, V.I. Allanite in Granites of the Verkhneurmiysky massif (Amur region). In Proceedings of the XLIX International Scientific Conference "Student and Scientific and Technical Progress", Novosibirsk, Russia, 16-20 April $2011 ;$ p. 23.

27. Leontev, V.I.; Skublov, S.G.; Shatova, N.V.; Berezin, A.V. Zircon U-Pb Geochronology Recorded Late Cretaceous Fluid Activation in the Central Aldan Gold Ore District, Aldan Shield, Russia: First Data. J. Earth Sci. 2020, 31, 481-491. [CrossRef]

28. Kempe, U.; Wolf, D.; Sala, M. Members of the philipsbornite-Florencite and chernovite-xenotime solid solution series in metasomatic altered granites of the Zinnwald tin deposit (Erzgebirge, Germany). Beih. Eur. J. Miner. 1999, 11, 120.

29. Pupin, J.P. Zircon and granite petrology. Contrib. Mineral. Petrol. 1980, 73, 207-220. [CrossRef]

30. Brodskaya, R.L.; Marina, E.Y.; Shnay, G.K.; Saminin, I.A. Restoration of conditions and formations kinetics of rare metal granites according to crystallomorphology of accessory zircon. Zapiski RMS 1986, 115, 50-62.

31. Nasdala, L.; Wenzel, M.; Vavra, G.; Irmer, G.; Wenzel, T.; Kober, B. Metamictisation of natural zircon: Accumulation versus thermal annealing of radioactivity-induced damage. Contrib. Mineral. Petrol. 2001, 141, 125-144. [CrossRef]

32. Corfu, F.; Hanchar, J.M.; Hoskin, P.W.O.; Kinny, P. Atlas of zircon textures. Rev. Mineral. Geochem. 2003, 53, 469-500. [CrossRef]

33. Geisler, T.; Schaltegger, U.; Tomaschek, F. Re-equilibration of zircon in aqueous fluids and melts. Elements 2007, 3, 43-50. [CrossRef]

34. Hay, D.C.; Dempster, T.J. Zircon behaviour during low-temperature metamorphism. J. Petrol. 2009, 50, 571-589. [CrossRef]

35. Vasilev, E.A.; Zedgenizov, D.A.; Klepikov, I.V. The enigma of cuboid diamonds: The causes of inverse distribution of optical centers within the growth zones. J. Geosci. 2020, 65, 59-70. [CrossRef]

36. Förster, H.-J.; Ondrejka, M.; Uher, P. Mineralogical responses to subsolidus alteration of granitic rocks by oxidizing As-bearing fluids: REE arsenates and As-rich silicates from the Zinnwald granite, eastern Erzgebirge, Germany. Can. Mineral. 2011, 49, 913-930. [CrossRef]

37. Ondrejka, M.; Uher, P.; Pršek, J.; Ozdín, D. Arsenian monazite-(Ce) and xenotime-(Y), REE arsenates and carbonates from the Tisovec-Rejkovo rhyolite, Western Carpathians, Slovakia: Composition and substitutions in the (REE, $\mathrm{Y}) \mathrm{XO}$ s system $(\mathrm{X}=\mathrm{P}, \mathrm{As}, \mathrm{Si}$, $\mathrm{Nb}, \mathrm{S})$. Lithos 2007, 95, 116-129. [CrossRef]

38. Pidgeon, R.T. Recrystallization of oscillatory-zoned zircon: Some geochronological and petrological implications. Contrib. Mineral. Petrol. 1992, 110, 463-472. [CrossRef]

39. Förster, H.-J. Composition and origin of intermediate solid solutions in the system thorite-xenotime-zircon-coffinite. Lithos 2006, 88, 35-55. [CrossRef]

40. Johan, Z.; Johan, V. Accessory minerals of the Cínovec (Zinnwald) granite cupola, Czech Republic: Indicators of petrogenetic evolution. Mineral. Petrol. 2005, 83, 113-150. [CrossRef]

41. Pettke, T.; Andreas, A.; Schaltegger, U.; Heinricha, C.A. Magmatic-to-hydrothermal crystallization in the W-Sn mineralized Mole Granite (NSW, Australia) Part II: Evolving zircon and thorite trace element chemistry. Chem. Geol. 2005, 220, 191-213. [CrossRef]

42. Hoskin, P.W.O.; Schaltegger, U. The Composition of Zircon and Igneous and Metamorphic Petrogenesis. Rev. Mineral. Geochem. 2003, 53, 27-62. [CrossRef]

43. Marin, Y.B. Accessory minerals of the granitoid series of tin and molybdenum provinces. Zap. Ross. Mineral. O-va 2004, 6, 1-7.

44. Tichomirowa, M.; Gerdes, A.; Lapp, M.; Leonhardt, D.; Whitehouse, M. The Chemical Evolution from Older (323-318 Ma) towards Younger Highly Evolved Tin Granites (315-314 Ma)-Sources and Metal Enrichment in Variscan Granites of the Western Erzgebirge (Central European Variscides, Germany). Minerals 2019, 9, 769. [CrossRef]

45. Hoskin, P.W.O. Trace-element composition of hydrothermal zircon and the alteration of Hadean zircon from the Jack Hills, Australia. Geochim. Cosmochim. Acta 2005, 69, 637-648. [CrossRef]

46. Kempe, U.; Gruner, T.; Renno, A.D.; Wolf, D.; René, M. Discussion on Wang. 'Chemistry of Hf-rich zircons from the Laoshan Iand A-type granites, Eastern China. Mineral. Mag. 2004, 68, 669-675. [CrossRef]

47. Poller, U.; Huth, J.; Hoppel, P.; Williams, I.S. REE, U, Th and Hf distribution in zircon from Western Carpathian Variscan granitoids: A combained cathodeluminescence and ion microprobe study. Am. J. Sci. 2001, 301, 585-876. [CrossRef] 
48. Kudryashov, N.M.; Skublov, S.G.; Galankina, O.L.; Udoratina, O.V.; Voloshin, A.V. Abnormally high-hafnium zircon from rare-metal pegmatites of the Vasin-Mylk deposit (the northeastern part of the Kola Peninsula). Chem. Erde 2019, 79, 1-8. [CrossRef]

49. Watson, E.B.; Wark, D.A.; Thomas, J.B. Crystallization thermometers for zircon and rutile. Contrib. Mineral. Petrol. 2006, 151, 413-433. [CrossRef]

50. Ferry, J.M.; Watson, E.B. New thermodynamic models and revised calibrations for the Ti-in-zircon and Zr-in-rutile thermometers. Contrib. Mineral. Petrol. 2007, 154, 429-437. [CrossRef]

51. Fu, B.; Page, F.Z.; Cavosie, A.J.; Fournelle, J. Ti-in-zircon thermometry: Applications and limitations. Contrib. Mineral. Petrol. 2008, 156, 197-215. [CrossRef]

52. Watson, E.B.; Harrison, T.M. Zircon saturation revisited: Temperature and composition effects in a variety of crustal magma types. Earth Planet Sci. Lett. 1983, 64, 295-304. [CrossRef]

53. Hanchar, J.M.; Watson, E.B. Zircon Saturation Thermometry. Rev. Mineral. Geochem. 2003, 53, 89-112. [CrossRef]

54. Boehnke, P.; Watson, E.B.; Trail, D.; Harrison, T.M.; Schmitt, A.K. Zircon Saturation Re-Revisited. Chem. Geol. 2013, 351, 324-334. [CrossRef]

55. Cao, Y.; Li, S.R.; Zhang, H.F.; Liu, X.B.; Li, Z.Z.; Ao, C.; Yao, M.J. Significance of zircon trace element geochemistry, the Shihu gold deposit, western Hebei Province, North China. J. Rare Earths 2011, 29, 277-286. [CrossRef]

56. Pelleter, E.; Cheillets, A.; Gasquet, D. A tool for ion microprobe U-Pb dating of gold mineralization (Tamlalt-Menhouhou gold deposit-Morocco). Chem. Geol. 2007, 245, 135-161. [CrossRef]

57. Balashov, Y.A.; Skublov, S.G. Unique indicator capabilities of cerium in zircons of different genesis. In Proceedings of the Conference Dedicated to the 110th Anniversary of the Birth of Acad. D.S. Korzhinsky, IGEM RAS, Moscow, Russia, 7-9 October 2009; pp. 67-70.

58. Kozhevnikov, V.N.; Ivashevskaya, S.N.; Kevlich, V.I. Geochemistry and Raman spectra of zircons from ore (PGE*Au) amphibolites of the Travyanaya guba massif, North Karelia. Proc. Karelian Res. Centre Russ. Acad. Sci. 2015, 7, 36-53. [CrossRef]

59. Nasdala, L.; Irmer, G.; Wolf, D. The degree of metamictization in zircon: A Raman spectroscopic study. Eur. J. Mineral. 1995, 7, 471-487. [CrossRef] 